\title{
Iran's Petroleum Policy: \\ Current Trends and the Future Outlook
}

\author{
ShIVA PEZESHKI \\ FEREIDUN FESHARAKI \\ Program on Resources: Energy and Minerals \\ East-West Center \\ Honolulu, Hawaii
}

\begin{abstract}
DISCLAIMER
This report was prepared as an account of work sponsored by an agency of the United States Government. Neither the United States Government nor any agency thereof, nor any of their employees, makes any warranty, express or implied, or assumes any legal liability or responsibility for the accuracy, completeness, or usefulness of any information, apparatus, product, or process disclosed, or represents that its use would not infringe privately owned rights. Reference herein to any specific commercial product, process, or service by trade name, trademark, manufacturer, or otherwise does not necessarily constitute or imply its endorsement, recommendation, or favoring by the United States Government or any agency thereof. The views and opinions of authors expressed herein do not necessarily state or reflect those of the United States Government or any agency thereof.
\end{abstract}

December 1994

Report prepared for the United States Department of Energy, Office of International Energy Assessments under Grant No. DE-FG01-90IE-10859 


\section{DISCLAIMER}

Portions of this document may be illegible in electronic image products. Images are produced from the best available original document. 


\section{Contents}

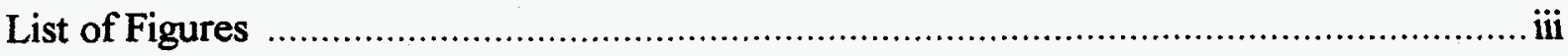

List of Tables

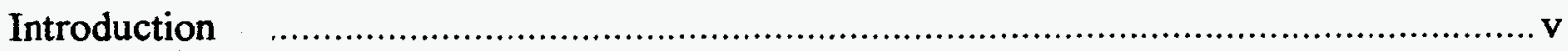



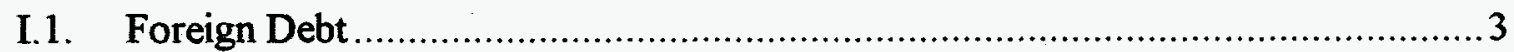

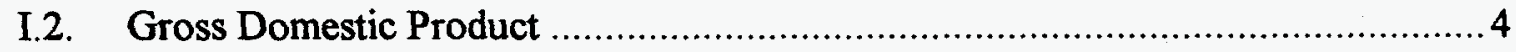

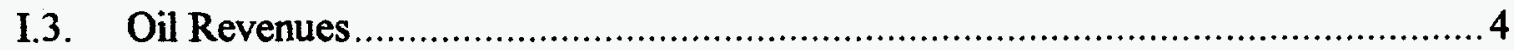

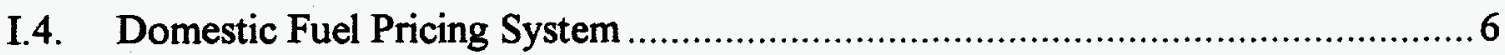

I.5. Private Investment and Privatization...................................................

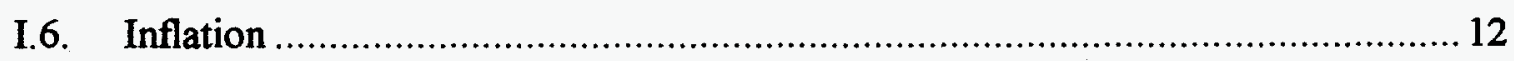

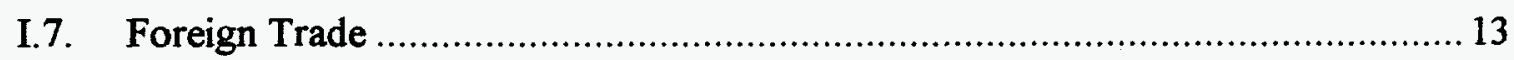

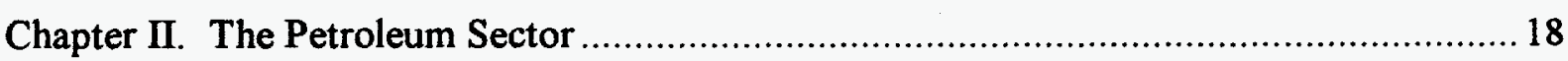

II.1. Oil Reserves, Production, and Capacity ............................................. 18

II.2 Petroleum Product Demand and Supply ............................................ 24

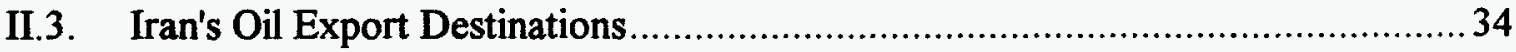

II.4. Emerging Relations with Central Asia ................................................. 39

Chapter III. Natural Gas and Petrochemicals ................................................ 43

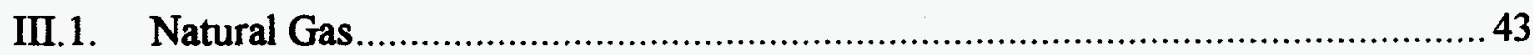

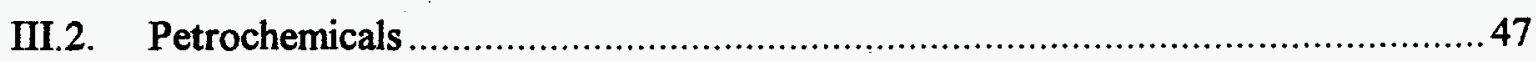

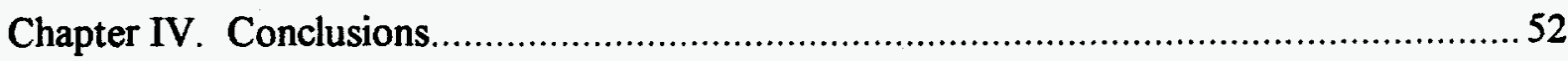




\section{Figures}

1. Average Annual Growth Rate of Gross Domestic Product, 1971-92 .................5

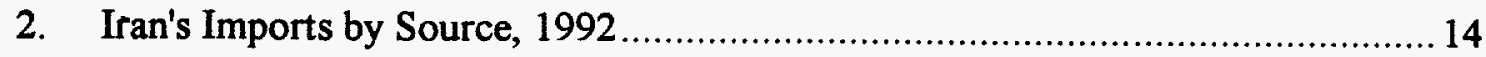

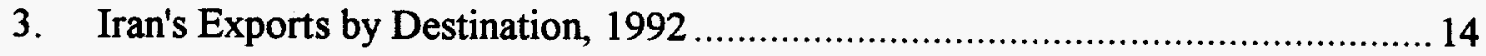

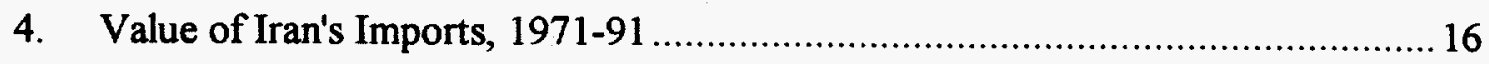

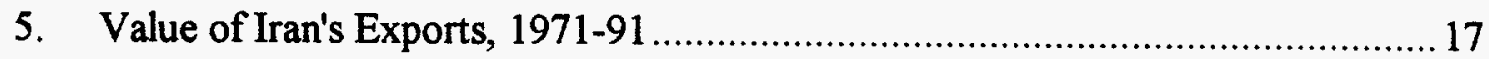

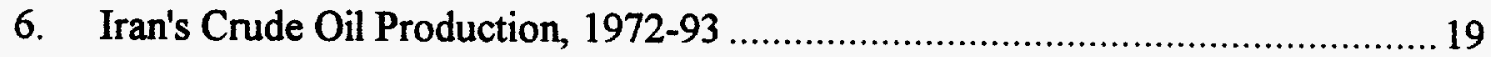

7. Iran's Crude Oil and Refined Product Exports, 1972-93 ................................ 20

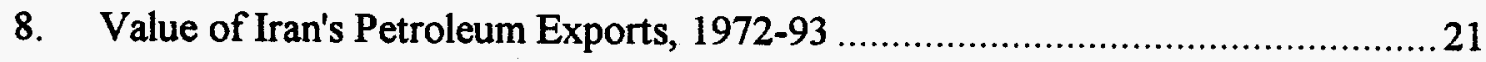

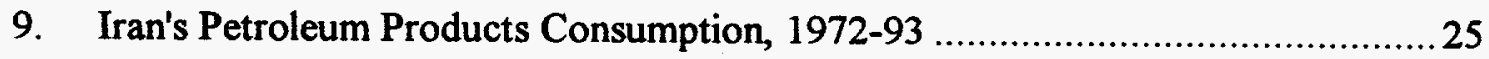

10. Iran's Oil Demand 1971-93 and Base Case Forecast to 2005............................. 30

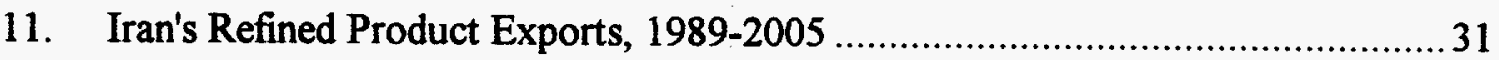

12. Base Case Projected Petroleum Product Balance, 2000 .................................... 32

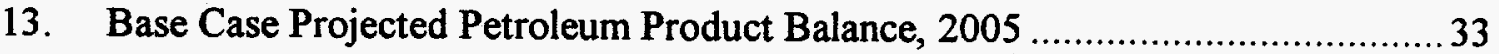

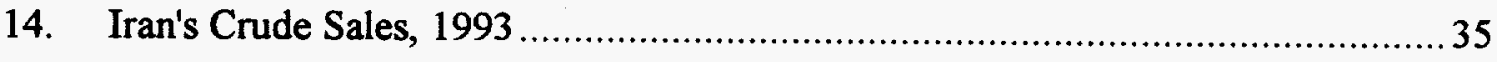

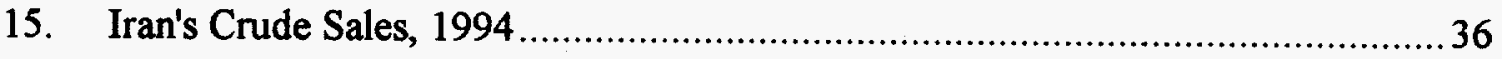

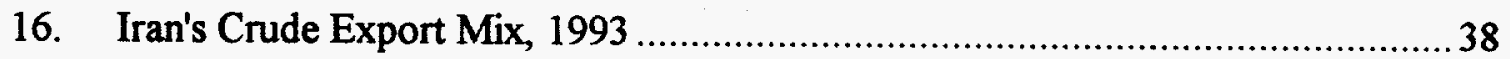

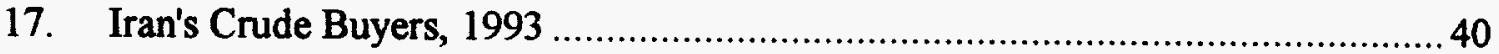

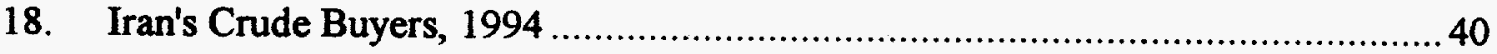




\section{Tables}

1. Domestic Petroleum Product Prices........................................................ 8

2. Summary of Iran's Petroleum Product Consumption, 1972-93 ......................... 27

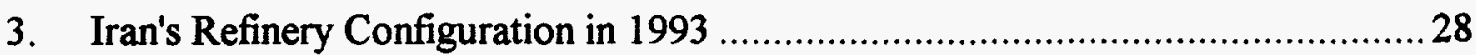

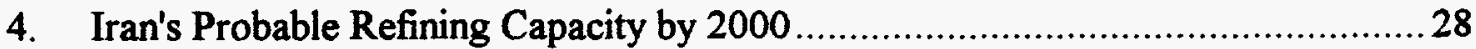

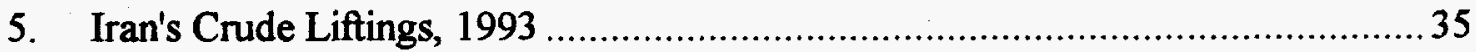

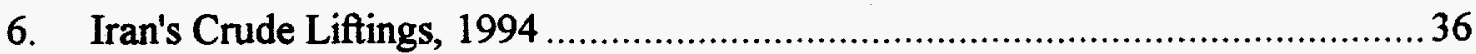

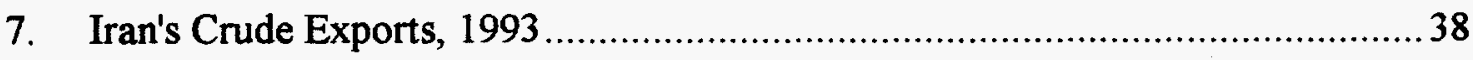

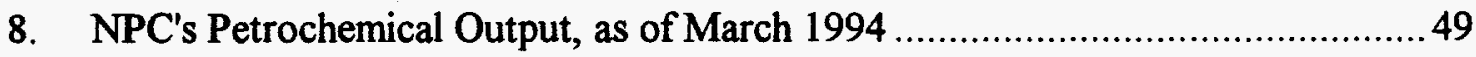




\section{Introduction}

The Iranian economy and political situation have undergone radical changes since the 1979 Islamic revolution. The excesses of the early years of the revolution have gradually given way to moderation and a more pragmatic economic policy-based on the principles of the free market. The economic policy changes were quite radical: eliminating subsidies, creating a single floating exchange rate with supply and demand movements, and introducing policies to reconstruct the depreciated infrastructure, to strengthen the industrial base and to make serious moves toward privatization. These changes have sent shock waves through the economic and political systems of the country. The economic reform program has dealt a heavy blow to vested economic and political interests. It led to unemployment, structural dislocations, rampant inflation, and the declining value of the Iranian currency, the rial. Indeed, the reform process may have progressed too fast in too heavy doses, but the essence of the program was the textbook economic reform usually advocated by the International Monetary Fund and the World Bank. The political ramifications have been serious, particularly because of the existence of different strong factions in the leadership of the Islamic Republic. As a result, the government has chosen to delay or even reverse certain policies. This change of direction will have extremely important long term implications for the Iranian economy.

The petroleum policy, as a subset of the economic policies, has been somewhat affected by the political and economic developments in Iran. The Iranian Oil Minister, Mr. Gholamreza Aghazadeh has been in office since 1986 and provides continuity to the oil policies of Iran.

The petroleum policy has changed from a position of no foreign participation to a position that includes a desire for foreign participation, the text of a model contract, and an attempt to introduce new technologies in the upstream sector. In the downstream sector, a variety of joint ventures have been discussed both at home and abroad. Strong arguments have been made to reduce subsidies for domestic consumption of petroleum products (which are sold at the lowest prices in the world) and to generate funds needed for upgrading, expanding, and modernizing the nation's refineries. All such attempts have been thwarted, however, by internal political disagreements over foreign investment and 
by opposition from those who fear the political consequences of a quick removal of subsidies. Despite the best of intentions, there has only been a marginal change in the oil policy compared with the past. Currently, there are no foreign joint ventures or work contracts in Iran, the price of petroleum products is heavily subsidized, and no serious move has been made to open up the local industry to international investment. This policy is sustainable in the short term, but it will have major negative long term repercussions. The sophisticated technocracy is aware of the problem, as are the Ministry of Petroleum and the National Iranian Oil Company (NIOC), but little can be done in the political atmosphere of today and possibly of the near future.

This report provides an overview of the key issues facing the Iranian oil industry and the economic context in which the oil industry is operating in Iran. It describes the evolution of policies meant to move the oil industry toward the free market; it discusses Iran's oil trading partners, the outlook for refining and project investments, and current and likely future developments in the natural gas and petrochemical sectors. In short, the report provides an up-to-date assessment of the Iranian petroleum sector and its likely evolution in the future. 


\section{Chapter I}

\section{Oil and the Iranian Economy}

The First Five-Year Economic Development Plan, initiated by the government of Mr. Rafsanjani in 1989, was aimed at reintroducing Iran into the world economy and launching market-based policies at home. However, due to opposition from the Majlis (Iranian parliament) and fundamentalist groups, the reforms have been progressing at a very slow pace. Still, several important steps have already been taken toward the liberalization of the economy. The following are some of the main points of the First FiveYear Economic Development Plan (March 1989-March 1994). ${ }^{1}$

- Reform of state-owned industry: In 1991, it was estimated that about 60 percent of the government's budget was spent on state-owned or affiliated companies. The reform aims to reduce this amount by limiting the access of these companies to deficit financing, and also in certain cases it may consider privatization. The government has been making efforts to persuade Iranians living abroad to repatriate capital and invest in state-owned industries. This measure has met strong opposition from fundamentalist groups in the country, and will probably take several years to slowly come into effect.

- Increased cooperation with the World Bank and International Monetary Fund: The government has stated its intention to try to increase its access to technical assistance and advice, as well as loans. Despite U.S. efforts to prevent all types of aid to Iran, in March 1993 the World Bank provided three loans to Iran for a total amount of US\$463.4 million, mostly to finance expansion and reconstruction projects in the petrochemical and oil industries. However, another loan of US\$450-500 million for a power generation program, and one of US\$1 billion for the offshore Dorood field gas reinjection project, were refused. Under U.S. pressure, no other World Bank loans to Iran are expected in the near term.

${ }^{1}$ Fiscal-year dates throughout this report are based on the Iranian year, which begins on 21 March and ends on 20 March of the following calendar year. 
Reform of the official exchange rate: Since 1990, Iran has been taking small steps toward reforming its unrealistic exchange rate mechanism, under which many items benefited from the subsidized rate of 600 rials to the dollar. In some cases, certain items were even priced at the prerevolution rate of 70 rials to the dollar. In April 1993, these rates were abolished, and the rial was devalued to a more realistic market rate. Everything was then priced at the floating market rate, which in April 1993 oscillated around 1,400 rials to the dollar. This new official rate has not stopped declining since November 1993 and reached 1,750 on 29 December of that year. On the open market the dollar is sold at higher rates, and at the beginning of May 1994 it actually rocketed to 2,880 rials. The higher short-term oil revenues in 1994 strengthened the Iranian rial against the US dollar, and as of 1 December 1994, 2,750 rials equalled US\$1 on the free market. On 4 May 1994 the year-old monetary reform came to a halt when the Central Bank announced the reintroduction of the multitiered exchange rate system to slow down the relentless devaluation of the rial. State banks will now offer dollars at a discount rate of 50 rials below the open market rate for certain imports. In October 1993, the Parliament also allowed the government to increase import taxes. Prior to the exchange rate reform, import taxes were still being assessed on the basis of the overvalued rial, and this increase in the tax rate was meant to make the increase in the prices of imported products much more perceptible. One of the priorities of the Second Five-Year Economic Development Plan is to reinstate the unified exchange rate, by gradually closing the gap between the two rates.

- Industrial expansion partly funded through foreign borrowing: Most of Iran's expansion and reconstruction projects are dependent on foreign funding and in particular the willingness of western banks to provide financing. Japan and France have provided financing for the reconstruction and expansion of the BandarKhomeini and Tabriz petrochemical plants. Over the past few years, banks have agreed to provide medium-term loans for project financing, as long as a national export credit agency supports the project. However, the international financial community has become more skeptical about Iran's credit-worthiness, given its rapidly deteriorating debt situation.

Iran's economy is heavily dependent on oil revenues. Although Iran is potentially a powerful and wealthy nation - thanks to its rich reserves and strategic location - its 
domestic recession, falling oil income, rising debt, and limited access to foreign credit greatly dampen the economic growth outlook for the near future.

\section{I.1. Foreign Debt}

Only a few years ago, at the end of the Iran-Iraq war, Iran's foreign debt was only about US\$6 billion, and all dues were paid on time. The major reason was that at that time it was imperative for Iran to cultivate and maintain international goodwill.

According to the Iranian Chamber of Commerce, Iran's medium-term foreign debt amounted to US $\$ 28$ billion at the end of 1993 . Since February 1994, Iran has managed to reschedule over US\$8 billion of the debts that will fall due by December 1994. Its first debt rescheduling was arranged with Germany for US\$2.6 billion, and then for US\$2.3 billion with Japan. Since then it has made arrangements with Austria, Switzerland, Denmark, Belgium, France, the Netherlands, and South Korea. Iran has also announced that it is close to reaching agreements with Spain and Sweden, but so far, there has been no confirmation. Most of these deals involve a grace period of two years and repayment over a period of the subsequent six years, although the exact terms and interest rates have not been disclosed.

The main reasons behind this rapid increase in foreign debt are, firstly, that Iran embarked on an ambitious five-year economic development plan with hard currency requirements of approximately US\$121 billion. Already in 1989, the Plan and Budget Organization announced the authorization by the Parliament of expenditures totaling US $\$ 12.9$ billion for specific projects. Of the total borrowings, more than 58 percent was dedicated to manufacturing projects. These included the development of Iran's natural gas reserves, construction of petrochemical complexes, as well as two dams on the Karoon River, in the southwestern province of Khusistan. Also authorized were imports for a total value of US\$10 billion of raw materials over the same period, on the condition that these industries would have to export their manufactured goods in order to contribute to the repayment of the loans, by earning back some of the hard currency. Iran's total debt at the end of the Five-Year Plan was supposed to reach US\$22.5 billion.

It is noteworthy that, despite the fact that Iran did not manage to borrow as much as it hoped, it now owes more money than it planned five years ago. Sluggish oil sales were a major contributor to the rising debt. Oil revenues were considerably lower than 
predicted. The government hoped for total oil revenues of about US\$78 billion over the five year period, or average annual oil sales of about US\$15.5 billion. However, the government's income from oil fell about US\$9 billion short of expectations. This was also the case for the non-oil exports which fell short by about US\$6 billion of the budgeted US\$17.8 billion.

Apart from low oil prices and the global recession, record imports, in particular in 1992 when imports reached US\$23.2 billion, were a major contributor to the critical debt situation of the country. The rush to benefit from the very low exchange rates, before the exchange rate reform took effect, caused significant foreign currency shortages in the country, and a US\$5.1 billion budget deficit for the year. The domestic market is still well stocked with imported goods, although for the year 1993, imports were reduced substantially to US\$13.1 billion, which still represents a large portion of Iran's oil earnings. The government is trying to reduce further Iran's borrowings and imports. For the Iranian year ending in March 1995, the Central Bank has slashed the foreign currency allocation for imports by another US\$6 billion compared with the previous year, reducing it to only US\$7 billion.

\subsection{Gross Domestic Product}

During the First Five-Year Economic Development Plan, total gross domestic product (GDP) grew at an average rate of 7.5 percent per annum, slightly lower than the planned 8.1 percent. This came after several years of negative growth rates (Figure 1).

The performance of the oil, gas, and transportation sectors were particularly strong during the First Five-Year Plan. The industrial and construction sectors, however, did not reach the same standards. These sectors were severely hit by the recession and the devaluation of the rial. In the 1994-95 budget, GDP growth of 6.5 percent has been forecast, and the oil sector is expected to grow 10.1 percent.

\subsection{Oil Revenues}

In 1993, over 80 percent of Iran's foreign exchange earnings were generated through oil exports. In December 1993, crude prices reached their lowest levels since 


\section{Figure 1:}

Average Annual Growth Rate of Gross Domestic Product, 1971-92




1988, and as crude prices continued to sink on international markets, the decline in oil income for the country has had devastating effects on the economy.

For the financial year ending 20 March 1994, the revenues from oil were budgeted at US\$17 billion based on a crude oil price of US\$16.5/barrel. However, at the end of the year, the government estimated that its oil revenues were only about US\$14 billion for that period. The budget for the fiscal year March 1994-March 1995 is based on oil export revenues of US $\$ 10.1$ billion, representing 58 percent of total projected revenues of US $\$ 18.4$ billion. This projection is based on a crude price of US $\$ 13 / \mathrm{barrel}$ and exports of only 2.25 million barrels per day (b/d). Given that oil prices have been higher than the level projected in the budget plan, oil revenues are expected to be US\$2-2.5 billion higher than budgeted.

One factor that may affect Iran's revenue for 1994 is Saudi Arabia's new production policy, whereby the production of Arab Heavy has been cut substantially. This action was taken with a view to gaining greater revenues from the higher-valued Arab Light crude. In response to Saudi policy, Iran has decided to boost its production of Iranian Heavy to capture the demand left unfilled as a result of the cut in Arab Heavy availability. In this regard it may appear that Iran has profited greatly from the Saudi policy. On the other hand, the demand for lighter crudes in the Far East has decreased at the same time. And since buyers are constrained by their contract commitments with Saudi Arabia, they have lowered their lifting of Iranian crude, despite the discount prices of Iranian Light compared with the equivalent Saudi grade. The cut in the sales of the higher-value Iranian Light, which offsets the gains from the greater Heavy grade sales, may prove to detrimentally affect Iran's revenues in the longer run.

In the draft of the Second Five-Year Plan, total oil revenues are projected at US\$64 billion, based on initial crude prices of US\$14/barrel in the early years and US $\$ 16 / \mathrm{barrel}$ in the late years of the plan. The Second Five-Year Plan has been postponed by one year, since the government felt that the country was not yet ready in March 1994 to start the second five-year reform program.

\section{I.4. Domestic Fuel Pricing System}

It is estimated that the Iranian government spends as much as US\$11 billion annually to subsidize 85-99 percent of the cost of various energy products. (In 
comparison, total energy consumption in the country amounts to only about US\$12 billion.) Subsidies have caused a serious distortion in the energy consumption pattern of the country. Fuel prices in Iran are among the lowest in the world. Table 1 shows the retail prices of petroleum products in Iran, in comparison with those in Europe. Assuming an exchange rate of 2,750 rials to one dollar, the starkest difference by far is that of the price of fuel oil: less than one-tenth of a US cent per liter in Iran, which is less than 1 percent of the average cost in Europe. Furthermore, at a mere 2.76 percent of the average European price (2.2 per liter in Iran, compared with $90.7 \notin$ in Europe), premium gasoline in Iran is clearly subsidized beyond the realm of normality. And while Europeans pay almost $59 \notin$ for a liter of gasoil, Iranians pay less than half of one cent.

Recent proposals by the government to increase domestic fuel prices by gradually cutting all subsidies during the Second Five-Year Plan were rejected by the Parliament. Later, the government approved a partial increase in prices, but even these minor increases were then rejected by the Supreme Guide Ayatollah Khamenei. Theoretically, the government is entitled to raise fuel prices unilaterally, but given the social and political sensitivity to the issue, it decided to put forward its proposal to the Parliament. This proposed partial increase in prices was part of the government's efforts to liberalize prices. It covered kerosene, gasoline, gasoil, and natural gas, as well as other governmentsupplied services such as electricity. Under the plan, the price of a gallon of gasoline would have risen from the current $10 \notin$ to $24 \notin$, an increase of 140 percent from the 1993 price. The price of jet fuel would have increased by 100 percent from 1993 levels. This plan could have been a major step in bringing Iranian domestic fuel prices closer to international levels.

The Iranian government still confirms its intentions to reduce the subsidies for energy products substantially during the next Five-Year Plan. The need for such action is clear, although owing to the social and political implications of such a move, the reduction will be very gradual. The optimal target, which seems too optimistic taking into account the difficulty of this task, would be to align Iranian domestic product prices with the international market level by the end of the Second Five-Year Plan. However, in light of the difficulties associated with price hikes, the government has recently proposed a gradual increase by the end of the decade. Finally, in response to the Oil Minister's warnings that without a price increase, there would not be enough funds for important projects such as the Bandar Abbas refinery due for completion in 1995, and some offshore-fields developments, the Parliament voted for a small price hike. Thus, the price 
Table 1: Domestic Petroleum Product Prices

\begin{tabular}{lccccc}
\hline Product & $\begin{array}{c}\text { Price in Rials } \\
\text { per Liter }\end{array}$ & $\begin{array}{c}\text { Price in } \\
\text { US Cents per } \\
\text { Liter (1) }\end{array}$ & $\begin{array}{c}\text { Average European } \\
\text { Retail Price in Cents } \\
\text { per Liter (2) }\end{array}$ & $\begin{array}{c}\text { Iranian Retail Prices as a } \\
\text { Percentage of the Average } \\
\text { European Retail Price }\end{array}$ & $\begin{array}{c}\text { New Iranian Retail Prices } \\
\text { as of 21 March 1995 in } \\
\text { Rials per Liter }\end{array}$ \\
\hline Gasoline (super) (3) & 60 & 2.18 & 90.73 & $2.40 \%$ & N/A \\
Gasoline (regular) (3) & 50 & 1.82 & N/A & N/A & 100 \\
Kerosene & 15 & 0.55 & N/A & $0.62 \%$ & 20 \\
Gasoil & 10 & 0.36 & 58.99 & $0.71 \%$ & 20 \\
Fuel Oil & 2 & 0.07 & 10.30 & 10 \\
\hline \hline
\end{tabular}


of gasoline will be doubled during financial year starting March 1995, to 100 rials per liter, and the price of a liter of diesel and kerosene will be increased to 20 rials. Fuel oil prices will reach 10 rials per liter, from the current level of only 2 rials per liter. Natural gas prices have also been proposed to increase by 20 percent from the current 20 rials per cubic meter. It must be noted that the proposed prices are in nominal terms. If we assume an inflation factor of 20 to 30 percent per anmum over the period of the five-year plan, the price of petroleum products would have to increase by a factor of 2.5 to 3 , just to keep up with inflation. This means that if the government wishes to see a real price increase, there has to be a radical price hike every year, so that by the end of the five-year plan, prices would be raised by up to 500 percent. A 500 percent price increase would bring Iranian prices to around $18 \notin$ per liter for gasoline and $4 \notin$ for gasoil and kerosene by the year 2000-still well below the international market price. In effect, if we discount the inflationary price increases, there effectively is not likely to be a substantial real price increase. As such, subsidies (measured in terms of the opportunity cost of exports) will continue to be very large, even under this plan. Given the expected further erosion of the Iranian currency in the international market, it may well be that the prices of petroleum products in Iran at the end of the Second Five-Year Plan would be even lower in U.S. cents per liter than they are today.

\section{I.5. Private Investment and Privatization}

One of the main goals of the First Five-Year Economic Development Plan was to encourage private domestic and foreign investment. Mr. Rafsanjani's administration embarked on a privatization program that was considered the means to accelerate industrial growth and to facilitate the reorientation of Iran's economy toward the market. Thus, the government started the transfer of ownership and management of certain industries and businesses back to the private sector through the Tehran Stock Exchange. After the revolution, the government took control of foreign trade, auto and machine tools and appliance manufacturing, textiles, mining, and higher education. Even many of the small consumer-products manufacturers became, one way or another, public properties and government controlled. These were over and above the nationalized industries, such as oil, electricity, and telecommunications, which were already under government control during the previous regime. 
Still, the privatization process remained very slow during the first three years of the plan. One reason was that only industries that were profitable and solvent would qualify to be put up for sale on the stock exchange. In practice, very few of the companies earmarked for sale were money-making businesses, and most of them were actually losing large sums of money. The government sought other ways to offer the stocks, such as offering them through banks, and even invited interested private parties for direct negotiations with the relevant ministries. High interest rates offered by banks on longterm certificates of deposit are considered by many to have discouraged stock market investments. On the other hand, serious recession and soaring inflation have not helped the situation. High inflation rates have actually boosted the purchase value of the stateowned companies, discouraging even more investors, both domestic and foreign.

It is important to note that the low profitability of industrial production (as opposed to quicker ways of money making such as dealing in the foreign exchange trade, imports, or real estate) contributed greatly to the poor performance of the stock exchange and thus of the privatization process.

According to the Plan and Budget Organization, gross investment for the year to March 1994 is estimated to have grown 8.9 percent. This is slightly below the average growth rate of 9.1 percent for the past four years. As a percentage of GDP, gross investment is expected to stand at 13.5 percent, which is 0.3 percent higher than last year. Over the period of the First Five-Year Plan, the gross investment growth rate was targeted at 14.4 percent, although in reality it reached only 13.1 percent.

A recent piece of legislation was supposed to define the legal framework for investment and operation in Iran's three free trade zones, in order to facilitate and encourage direct foreign investments in the country. A number of investors, however, say that its provisions are too vague. The free trade zones are located in the south of the country and cover the entire island of Kish, 300 square kilometers in the northeast of the island of Qeshm, and 140 square kilometers of Chah Bahar Port. Incentives for investment in these zones include a fifteen-year tax exemption for all production and service operations, no import tariffs, no export tariffs for non-oil goods manufactured for export purposes, free flow of capital, and unrestricted ownership of business shares by foreign nationals. However, the right to buy land is awarded only to Iranian nationals, while foreign investors may only lease the land. In this legislation, there are also provisions for the establishment of joint ventures in the banking sector between domestic and foreign banks, in order to facilitate and accelerate the transfer of funds. 
This law had already been approved once by the Parliament in the summer of 1993. However, it was rejected by the Council of Guardians - the body responsible for ensuring that new laws conform with the tenets of Islam. Even after having been revised following the guidelines of the Council, the legislation was still subject to fierce criticism. According to the critics, the rapid rise of the dollar against the rial in December was to be blamed on the free trade zones, where scarce dollars were being used for cheap imports into the country. Consequently, the government has announced the abolition of liberal import policies. Indeed, the ambitious Qeshm Island planned joint-ventures seem to have encountered a major setback with the failure of the authorities to attract foreign investment. The Iranians were hoping that Qeshm, the largest island in the Persian Gulf, would become a rival to Dubai's Jebel Ali special economic zone. However, none of the major projects vital to its success as a free trade zone have taken off thus far - the most important being a deep-water port that could accommodate large vessels. Qeshm is now connected to the national electricity grid, and has several hundred kilometers of paved roads. Nevertheless, not much progress has been made as far as the projects involving foreign investment are concerned. Out of the many projects agreed on paper, such as the construction of a power plant by Germany's Siemens, and a fertilizer plant with Indian interests, only one - that of a hotel with Malaysian investors - has actually gone beyond talks, and is under construction.

Iran has been trying hard to encourage foreign investment in the oil and gas sector, in particular to fulfill its future expansion plans. Although production sharing or equity agreements granted to foreign companies is prohibited by the Iranian constitution for the time being, Iran is actively seeking service contracts under which foreign companies would participate in exploration and development of the fields. In the Second Five-Year Plan, there is a proposal for an investment of about US $\$ 30$ billion in the oil and gas sector. Of this, US\$16.6 billion has been earmarked for government financing in the oil sector, US\$3.8 billion is allocated to gas, and US\$9 billion of foreign money in the form of foreign credit would be invested in the energy sector in general. So far, the Parliament has granted NIOC the authority to raise US\$3.5 billion of foreign financing, with the condition that lenders would enter buy-back agreements with the oil ministry.

In early 1994, after not so fruitful attempts to attract foreign funds into the Iranian energy sector, the government also formed a new company, the Iranian Offshore Engineering and Construction Company, the task of which is to seek out foreign joint ventures with international engineering companies. The aim is that the foreign partners 
would use their international standing and reputation to help raise funding for oil field developments, and would then manage the operations.

However, Iran's debt problem has made most foreign investors wary of entering any deals with Iran. The country's current economic situation and all the rescheduled debts do not inspire any confidence in potential investors who are waiting to see if Iran can meet its deadlines for payment this time. Under the two-year grace period accorded for most of the rescheduled debt, no payments will be due before 1996. This makes the short term prospects for foreign involvement in Iran's increasingly capital-intensive projects more gloomy.

\section{I.6. Inflation}

According to the First Five-Year Economic Development Plan, the inflation rate was to be reduced to 8.2 percent by March 1994, from its high levels of 40 and 60 percent. However, the Central Bank's official figures show an inflation rate of about 26 percent for the year that ended in March 1994. During the Iranian year 1371 (March 1992-March 1993) inflation was at 21 percent, compared with 29.1 percent the previous year. Among the factors contributing to high consumer prices, the devaluation of the rial and cuts in certain government subsidies have had major impacts. A bill recently introduced by the members of the Parliament calls for authority to fix prices to be handed over from the High Economic Council to the Parliament. The High Economic Council, which is a government body headed by President Rafsanjani, and involves key economicrelated ministries, is currently responsible for setting the price of many goods and services. The enactment of this new bill would mean the reversal of many of the price reforms initiated by the government. While the general public, which has been suffering for a long time from high inflation, welcomes such a step, the industrial community's reaction has been much more negative. Because of major cuts in subsidies, these units have had to increase their prices substantially in order to survive, and they would be particularly hit by this decision. Most of these factories, which are state-owned, would either have to go out of business, or the government would need to reestablish the subsidies. The latter option would, however, mean a bigger budget deficit and would therefore hoist inflation again instead of curbing it. 


\subsection{Foreign Trade}

The volume of trade fell dramatically after the Iranian revolution, and it did not start to pick up again until the war with Iraq was over. Since then, the growth has been significant, jumping to about 46 percent for exports and 67.5 percent for imports between 1988 and 1989. Industrialized countries have been the major trade partners for Iran for a long time (Figures 2 and 3). In 1992, they absorbed 73 percent of Iran's exports and were the source of 64 percent of its imports. Among the industrialized countries, Germany was Iran's single largest source of imports in 1992 to the tune of US\$5,612 million, or 24 percent of total imports to the country. It was followed by Japan for US\$2,918 million, Italy for US\$2,253, the U.K. for US\$1,108 million, and the United States for a total value of US\$822 million. Iran's imports from the United States resumed in 1990 after an interruption of several years, and have been increasing ever since. Even during the period of 1992-93, when Iran was undergoing financial difficulties, the U.S.-Iran trade declined by a mere 10 percent, from US\$747.5 million to US\$616.2 million. The imported items included gas turbines, oil and gas machinery parts, and agricultural goods such as rice and maize. According to the U.S. Department of Commerce, the trade ban imposed on Iran by the U.S. government applies mainly to items that could be potentially used in the production of nuclear, biological, and chemical weapons, missiles, and aircraft. However, in 1992, the National Defense Authorization Act allowed the reestablishment of exports to Iran of "low-level manufactured items" such as general industrial, construction, electric power, computer, and medical equipment. Recently, the volume of imports of U.S. goods into Iran has dropped substantially because of Iran's financial difficulties and import restrictions implemented by the government. For the first quarter of 1994, Iranian imports from the United States totaled US\$90 million, compared with US\$217 million during the first quarter of 1993. It is necessary to underline that Iran has no restrictions on the import of U.S. goods into the country. As for imports into the U.S. of Iranian goods, despite the ban imposed since 1987, American oil companies have been major buyers of Iranian crude, although only for use and distribution outside the United States. In 1992, the largest volume of Iran's exports went to Japan (US\$2.4 billion), Italy (US\$1.5 billion), the Netherlands (US\$1.3 billion), France (nearly US\$1 billion), and Belgium (US\$943 million). Germany, the largest exporter to Iran, on the other hand, ranked only sixth among the importers of Iranian products, with only US\$660 million of imports in 1992. Asia, which absorbed up to 19 percent of Iran's total exports in 1992, was the source of only 9 percent of the imports into Iran. 


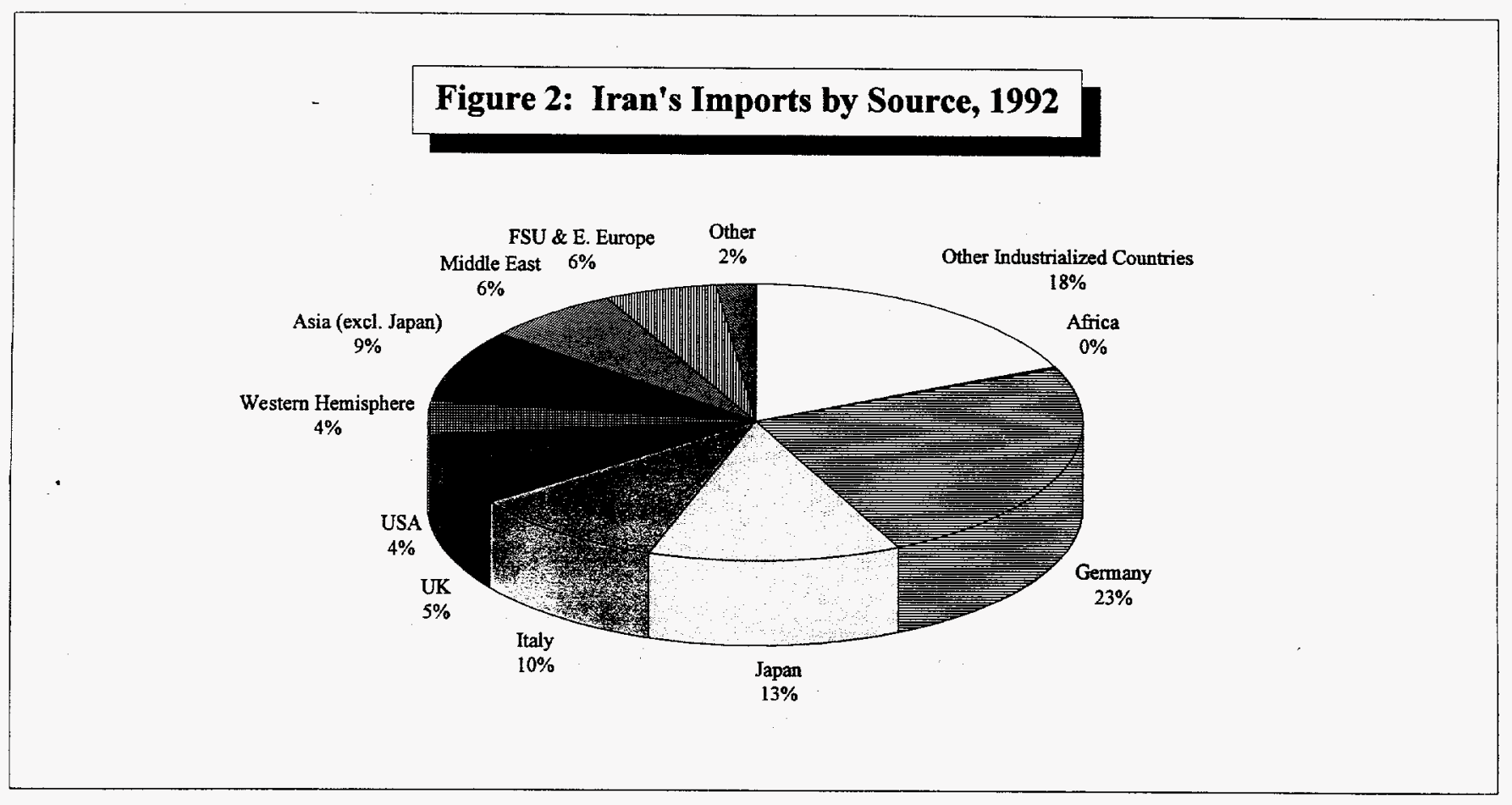

\section{Figure 3: Iran's Exports by Destination, 1992}




Figures 4 and 5 show the value of Iran's imports and exports between 1971 and 1991. As can be appreciated from the figures, oil constitutes the greatest portion of the country's export earnings, and manufactured goods are the major imported products. Manufactured goods over this period made up on average about 86 percent of the total imports into the country. In 1991, total imports stood at US\$21.7 billion, and the value of the imports of manufactured goods was US\$17.8 billion. As for exports, their total value reached US $\$ 15.9$ billion, and the fuel exports alone (US\$14.2 billion) represented roughly 89 percent of the total. Over the 20 year period between 1971 and 1991, the share of fuel exports in total exports was around 95 percent. The share of Iran's non-oil exports has been increasing steadily over the past few years. In the last year of the First Five-Year Plan (March 1993-March 1994), non-oil exports reached US\$4 billion, compared with only US\$750 million during the first year of the plan (1988-89). This represents an increase of nearly 40 percent over the five-year period. Iran aims to increase this figure to US $\$ 5$ billion by March 1995 . The principal products exported were carpets, steel, pistachio nuts, copper, chemicals, and some other agricultural products. 
Figure 4: Value of Iran's Imports, 1971-91

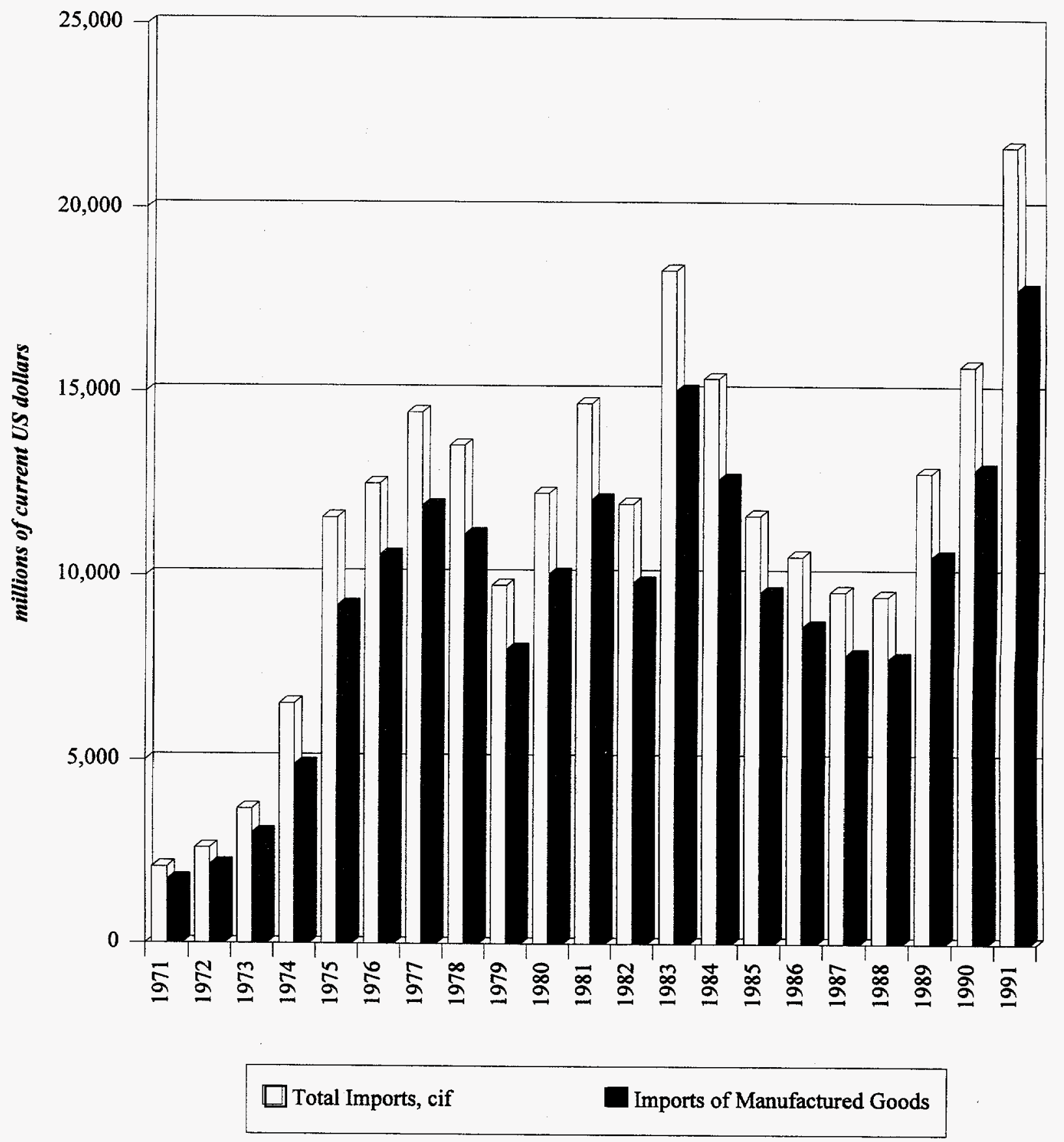


Figure 5: Value of Iran's Exports, 1971-91

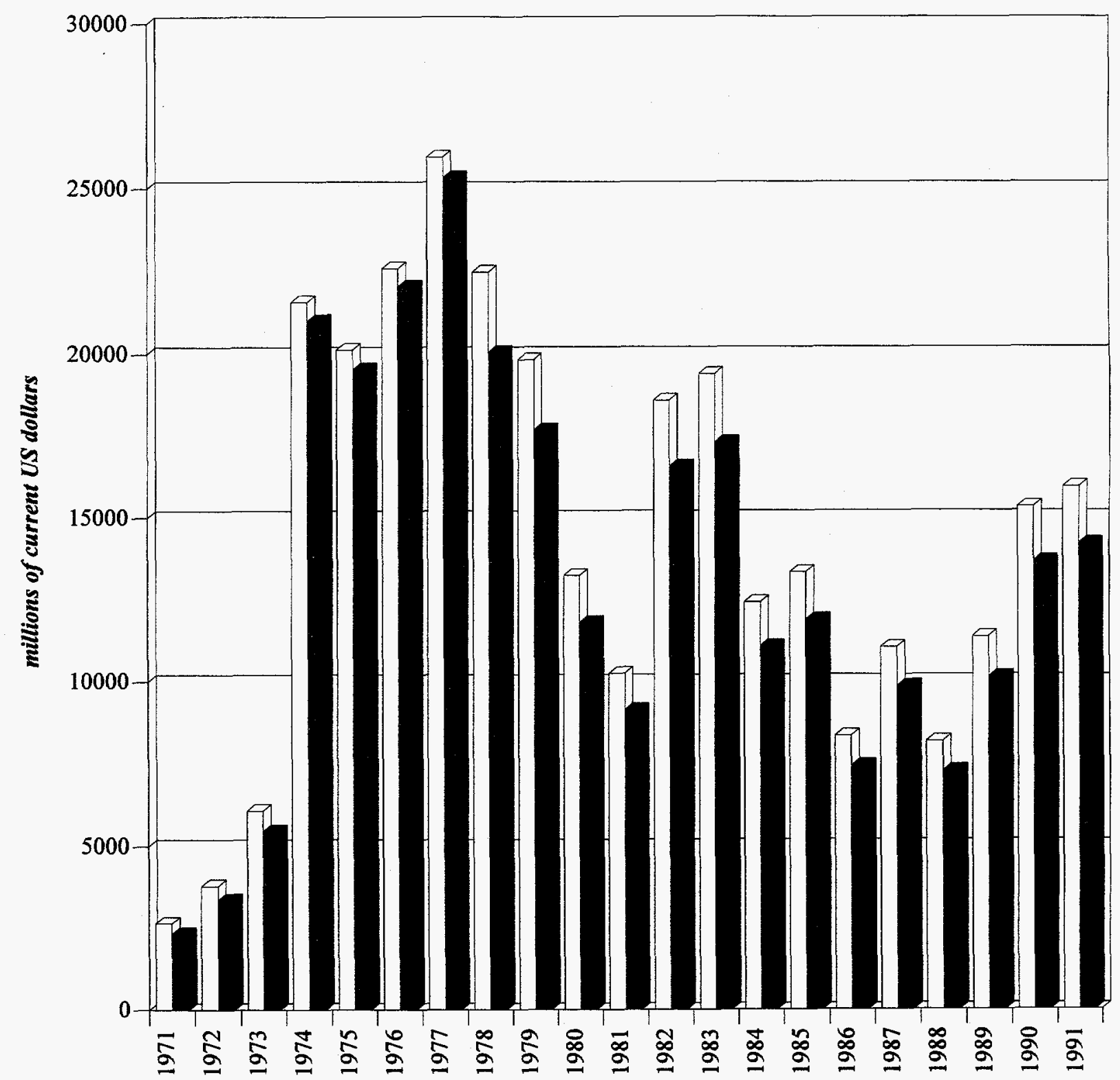




\section{Chapter II}

\section{The Petroleum Sector}

The petroleum sector is the most important industrial sector in Iran. With 80 percent of the total foreign exchange earnings generated by oil, this industry has been, and will continue to be, the mother of all industries in this country. In this chapter, we examine the present situation of the petroleum sector, and its likely prospects into the next century.

\section{II.1. Oil Reserves, Production, and Capacity}

Iran is estimated to have oil reserves of 92.9 billion barrels, ranking fifth in the world, with almost 10 percent of total world reserves.

Major efforts have been made in Iran over the last few years after the Iran-Iraq war to boost production capacity, and recover international market share. However, prerevolution crude production levels of over 6 million b/d are still not within reach. During the war, lack of investment and maintenance seriously undermined the oil industry in Iran. Over the period 1982-88, production oscillated between 2.0 and 2.4 million b/d. The recovery since then has progressed at a slow but steady pace. Figure 6 shows the crude production rates in Iran since 1972. Iran's oil production and exports have fluctuated greatly (Figures 7 and 8), owing to turmoil that affected the country over this period, and are much lower today than they were 20 years ago.

One of the targets of the First Five-Year Plan was to boost crude production capacity up to a sustainable level of 4.5 million b/d. Production capacity for 1993 reached around 4.2 million b/d, of which 3.65 million b/d came from onshore fields. In mid-1994, total sustainable capacity is estimated to hover between 3.7 and 3.8 million $\mathrm{b} / \mathrm{d}$. 
Figure 6:

Iran's Crude Oil Production, 1972-93

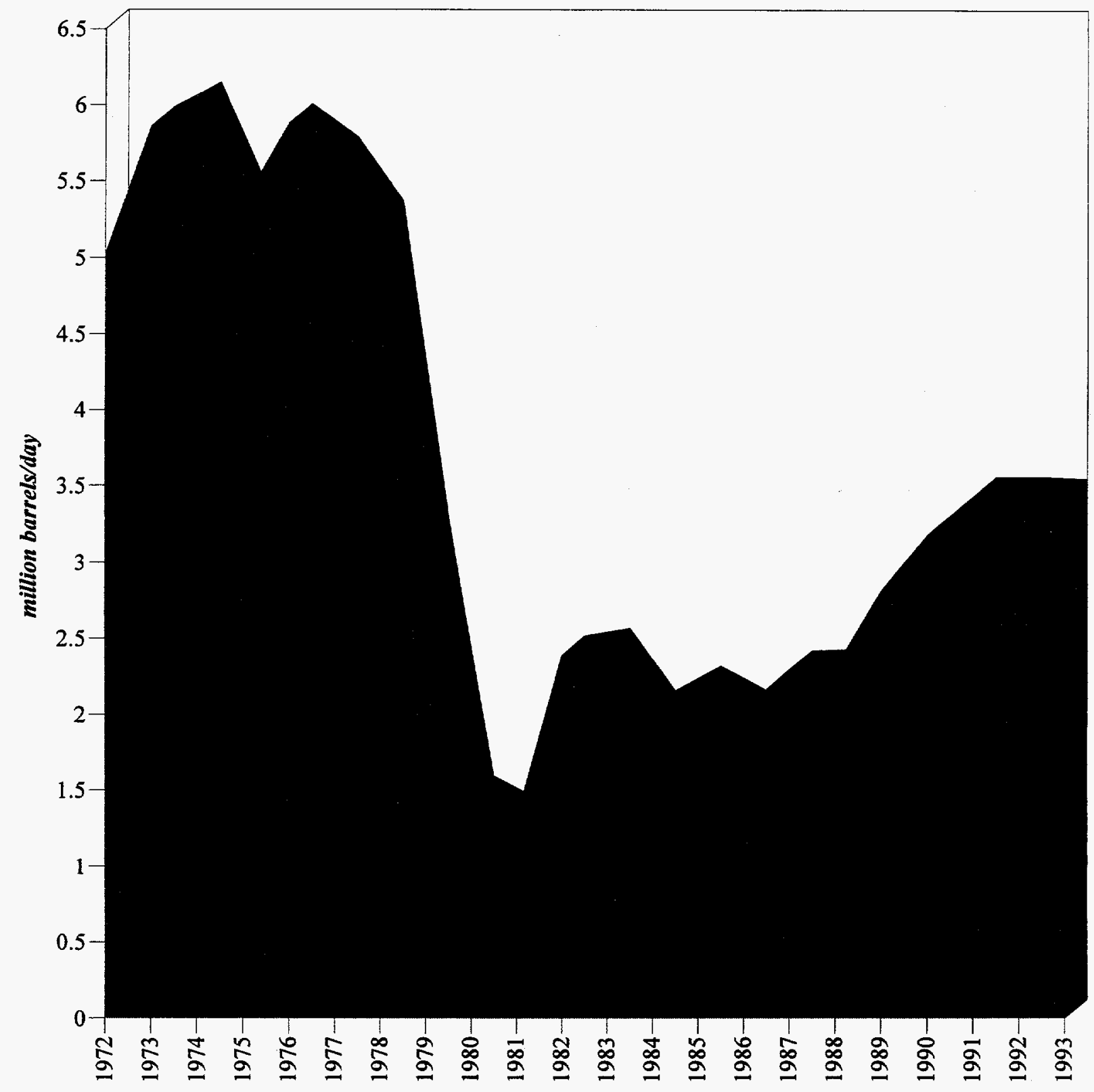


Figure 7:

Iran's Crude Oil and Refined Product Exports, 1972-93

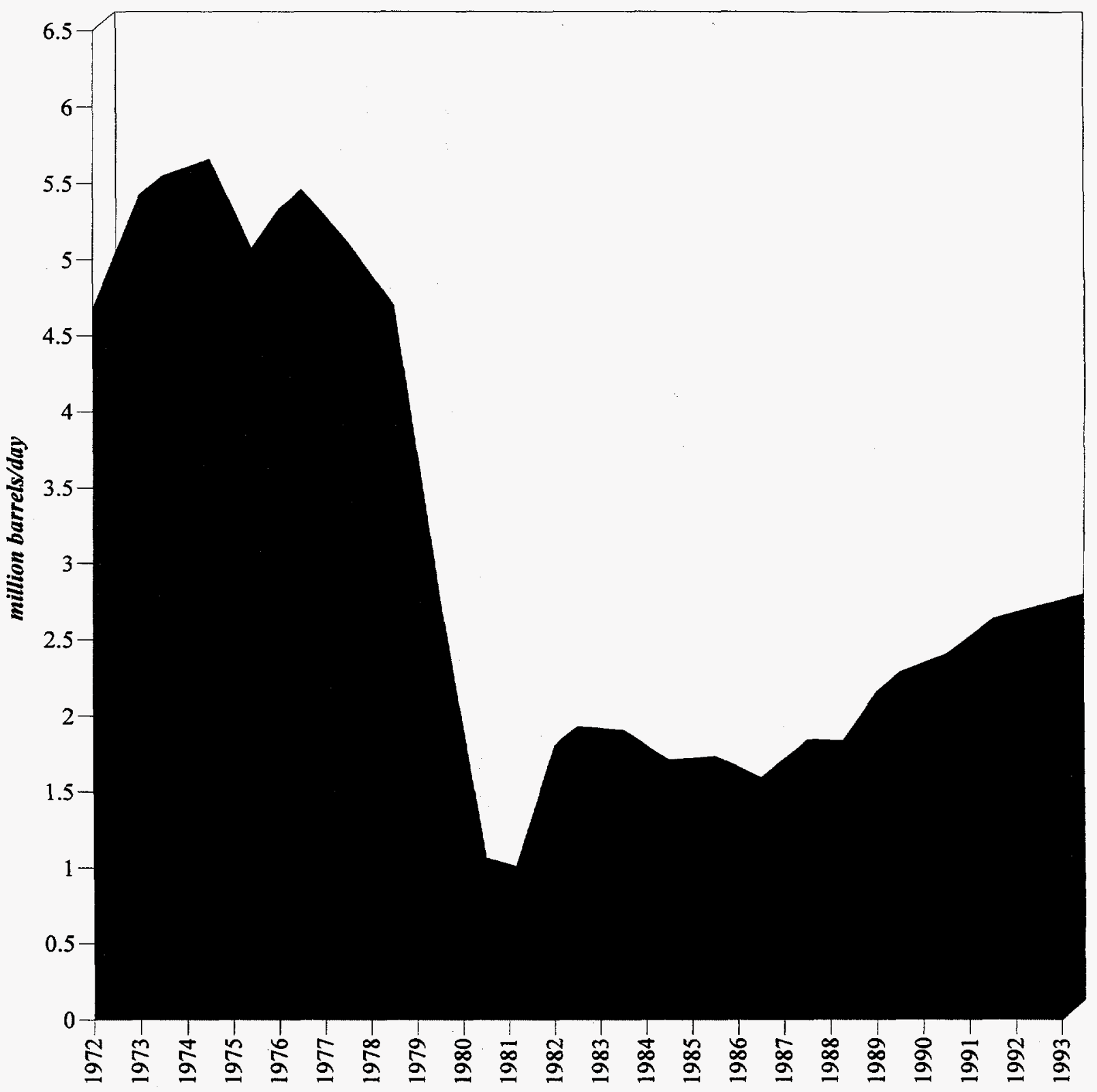


Figure 8:

Value of Iran's Petroleum Exports, 1972-93

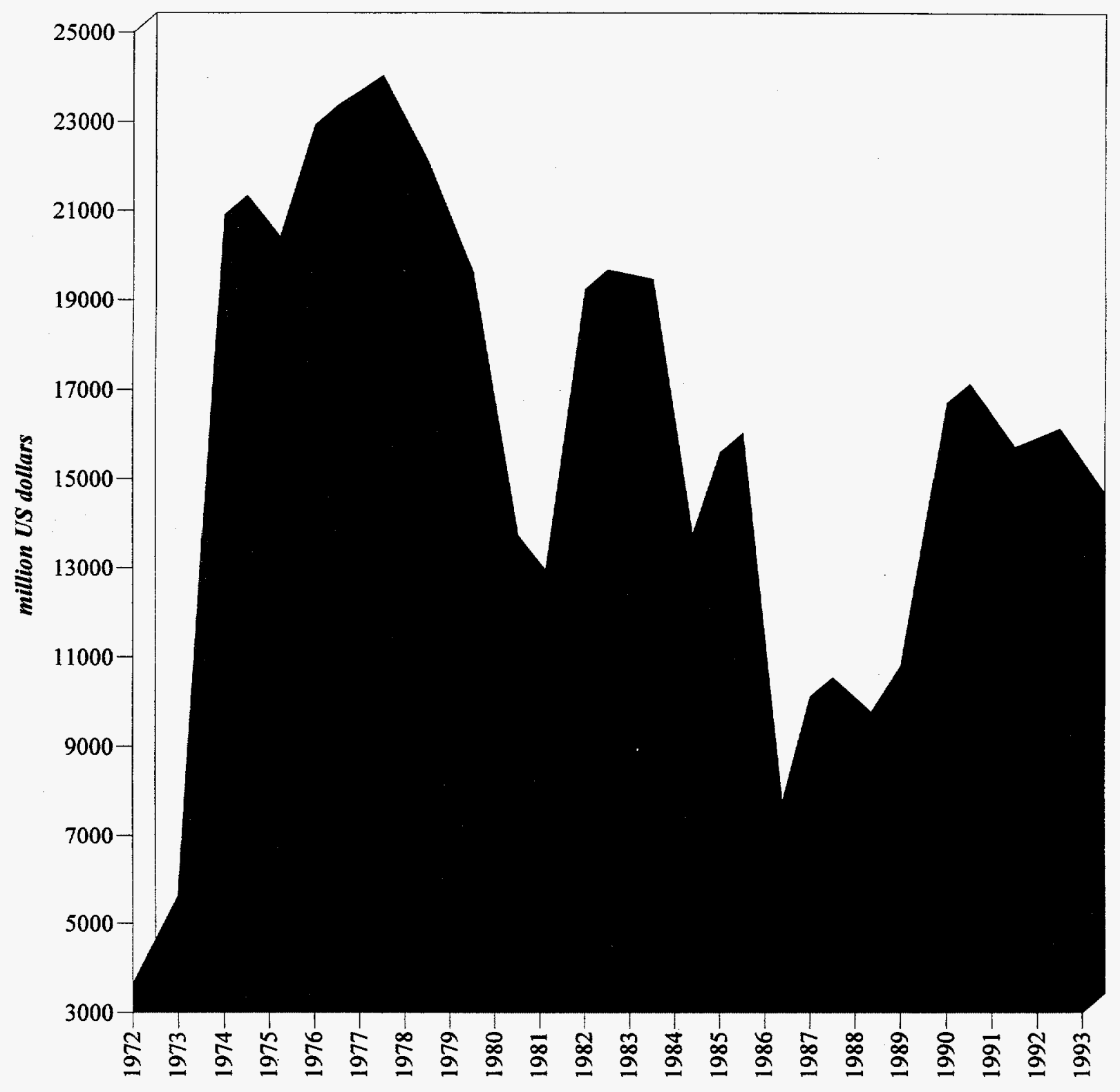


Capacity increases planned for 1995 in major oil fields are as follows:

- Production capacity at Ahwaz-Asmari field planned to reach 850 thousand b/d from 835 thousand b/d in 1993;

- Ahwaz-Bangestan field planned to produce 180 thousand b/d, compared with 155 thousand b/d in 1993;

- 150 thousand b/d of incremental capacity at Gachsaran, to reach 750 thousand b/d;

- Sustaining a production capacity of 270 thousand b/d at the depleting Agha Jari field, currently producing at its full capacity of 250 thousand b/d;

- Addition of 30 thousand b/d at the Marun oil field (570 thousand b/d in 1993);

- Finally, new oil fields of Delhuran, Gulkhari, Danan, Paydar, Paydar Gharb, Ghalendar, Zagheh, and Zeloi, each with potential capacity of 50 thousand b/d .

In August 1994, Iran awarded the reconstruction of the Abuzar oil fields, which were seriously damaged during the Iran-Iraq war, to a joint venture company formed by NIOC and a subsidiary of the Ministry of Heavy Industries, Idro. The joint venture company is called the Iranian Offshore Engineering Construction Company (IOEC) and intends to complete the project by 1997. The project, costing an estimated US $\$ 130$ million, involves the construction of new platforms and boosting the production of the Abuzar fields from 75 thousand $b / d$ to 150 thousand $b / d$. This project was originally awarded to a consortium consisting of the United States' McDermott, France's EPTM, and Japan's Tomen, but the negotiations collapsed for lack of financing.

Gas reinjection schemes are vital to the completion of these plans. So far, reinjection is operational in four fields: Gachsaran, Haft Kel, Marun, and Karanj. Projects were planned for Karanj, Parsi, Agha Jari, Bibi Hakimeh, Raj-e-Sefid, Binak, and Kupal in 1993. However, the cut in oil revenues and lack of financing, in particular the lag in the development of both the North and South Pars gas fields, have put off the completion of many of these projects for the near future. For 1995, Iran plans to improve production (1) at Karanj - to produce at full capacity of 225 thousand b/d from only 100 thousand $b / d$ in 1993; (2) at Parsi - to start production and increase to 200 thousand b/d; and (3) at Agha Jari (250 thousand $b / d$ in 1993) and Bibi Hakimeh (130 thousand $b / d$ in 1993) - to increase production capacity by 20 thousand $b / d$ each. The South Pars project was 
initially supposed to be developed by a consortium led by Italy's TPL, but was canceled for lack of financing. As for the North Pars project, Shell started a joint study of the fields with Iran in June 1993. Although some progress has been made in the talks between Shell and NIOC, no agreements have been reached on the form of repayment to Shell for the development of the fields. Besides the North and South Pars, several other fields have been offered for joint-ventures with foreign companies, including Balal, Sirri E, Sirri A, and Hengam.

These joint ventures would be only in the form of service contracts. Many companies, such as Shell in the case of North Pars, seek a share in the production. However, at present the Iranian constitution does not allow NIOC to grant any production sharing and/or equity in the fields. Financiers require some form of security in order to provide funds for the projects, and it seems that access to oil production could provide such guaranties. However, until such time that these forms of joint-venture are permitted in Iran, it will be very difficult to find financing for projects. Iran has been holding talks with France's Total and the United States' Conoco regarding a US\$500 million contract for the development of the oil structures of Sirri A and E. The two fields, for which Total and Conoco are competing, have a cumulative production of over $100,000 \mathrm{~b} / \mathrm{d}$, and some condensate. They have estimated cumulative reserves of nearly 490 million barrels. There are still many uncertainties regarding the project, starting from the minimum percentage of local participation, to more delicate matters such as pricing.

It appears that if Conoco wins the contract, it would use the gas for reinjection into some of its reservoirs in nearby Dubai. Some crude may also be included in the form of repayment for the development costs, as the gas supplies may be insufficient. The appointment of Conoco for this contract may well cause some discomfort in the U.S. government, given the fact that it will be the first U.S. company to invest in Iran since the introduction of the Clinton administration's "dual containment" policy toward Iran and Iraq.

The Sirri project would be the second potential offshore development, and until most recently, was expected to be the last for a while, since owing to cash shortages the rest of the offshore fields rate low in priority on the government's current agenda. However, it appears that there have been talks that Arco may be interested in the offshore Balal oil fields, which were discovered nearly 15 years ago by a joint venture between NIOC and several U.S. firms, including Arco. The production potential from the Balal fields is estimated at 35 thousand $b / d$, and a pipeline already connects the fields to the 
Lavan export terminal. There are also rumors that other European and U.S. firms have shown interest in the development of fields that were discovered by Mobil and Elf Aquitaine, in the strait of Hormuz, a long time ago.

On the other hand, foreign participation for the development of the onshore fields would face fierce political opposition within the country. Exploration and drilling activities increased notably in 1993. In the Second Five-Year Plan, starting in March 1995, there are plans to drill more than 300 new onshore and offshore wells in order to raise the crude production capacity. During these five years, NIOC has set its targets to discover annually around 200 to 400 million barrels of oil, and 5 to 10 billion cubic feet of natural gas. Obviously, no discoveries of huge reserves are expected. There are plans to use at least seven onshore exploration rigs, and three offshore, till the end of the decade. However, in order to achieve these goals, Iran will certainly need some foreign assistance. It has already invited bids from foreign companies for three offshore rigs, two of which are located in the Persian Gulf, and the third is in the much disputed waters of the Caspian Sea.

Reconstruction efforts since the end of the war in 1988 have also been intense. The eight-year war extensively damaged the oil fields, in particular those located offshore. Just before the revolution, the production capacity of Iran's offshore fields averaged 600 to 700 thousand $b / d$, with actual production of about 600 thousand $b / d$. Since the end of the war, part of the production capacity in the offshore fields has been restored. In 1992, offshore production reached 250 thousand b/d, in 1993 it leaped to 460 thousand b/d, and it is targeted to reach 645 thousand $\mathrm{b} / \mathrm{d}$ in the near future.

\section{II.2. Petroleum Product Demand and Supply}

Although crude production has fluctuated greatly over the past couple of decades, domestic consumption did not cease to increase over the same period, and was not affected by the political problems in the country to the same extent (Figure 9). The demand for petroleum products in Iran has grown from 244 thousand b/d in 1972 to an estimated 1.1 million b/d (excluding bunkers) in 1993 - an average annual growth rate of about 8 percent. Over the $1979-80$ period - the year of the Islamic revolution consumption of petroleum products underwent a negative growth rate, because of the lack of availability of products on the market. After that, the demand started to pick up once again, until 1982 when the war between Iran and Iraq broke out. The war slightly slowed 


\section{Figure 9:}

Iran's Petroleum Products Consumption, 1972-93

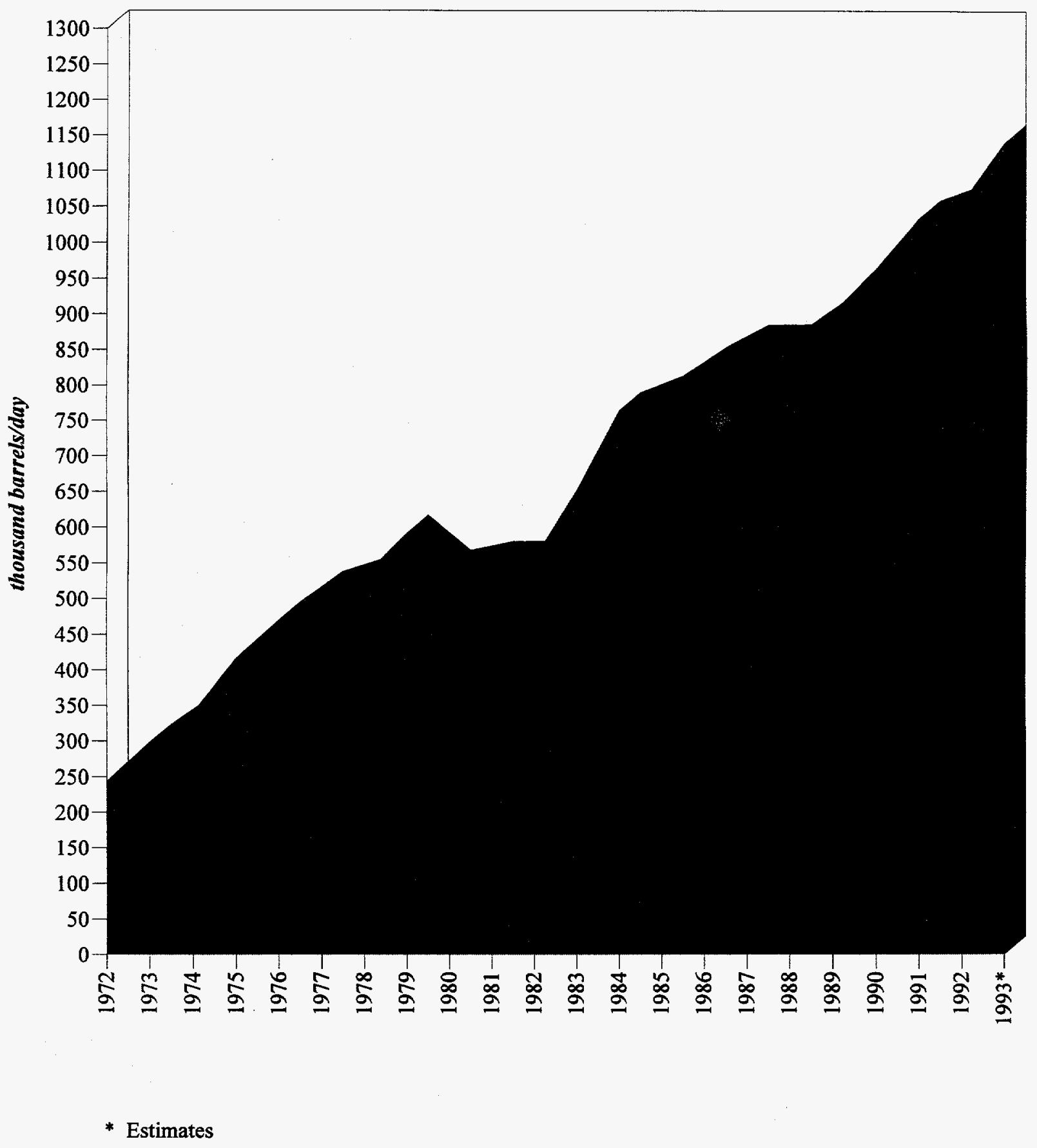


down the demand for that year. However, the interruption in growth of petroleum product consumption was very temporary, and by 1983, demand was growing once again at rates of around 17 percent. Since then, it has been fluctuating slightly, but continued to grow at a relatively rapid rate. As in many other developing countries, middle distillates, mostly diesel, constitute the biggest share of the total petroleum product demand (Table 2). In 1992, the demand for diesel reached about 358 thousand $b / d$, while gasoline demand stood at nearly 159 thousand $b / d$.

A major reason behind the high growth rate for energy demand is the population boom over the past 20 years. Iran's population currently stands at 60 million, and is expected to double over the next 20 years. In addition, high subsidies and thus cheap fuels have encouraged major wastage of energy in the country. Domestic consumption of oil products for the period of March 1993-March 1994 rose above 1 million b/d, or almost a third of total production.

In the refining sector the reconstruction has been somewhat slow. Tables 3 and 4 show Iran's refinery configuration in 1993 and 2000. Most of the existing facilities are running at well below capacity and have still not recovered from the damages sustained during the war. Arak I, the first grass-roots refinery to be built since the revolution, was officially opened in September 1993. This refinery, which uses Ahwaz-Asmari crude, has a capacity of 140 thousand b/d. The plant produces daily 6,695 barrels of LPG, 6,670 barrels of light naphtha, 12,120 barrels of gasoline, 8,890 barrels of reformate (used as feedstock for the Arak petrochemical plant), 26,910 barrels of kerosene, 37,590 barrels of fuel oil, 46,503 barrels of gasoil, and 5,560 barrels of asphalt. This new refinery brings the total refining capacity of Iran up to 985 thousand b/d and is expected to save the country as much as US $\$ 440$ million every year in product imports. Iran plans to increase its total refining capacity to 1.4 million $b / d$ by the end of the decade.

There are also plans to add 100 thousand b/d of capacity to the Abadan refinery. However, the budget for this project is yet to be finalized, and therefore the completion date is still unknown. Small additions will also be made to the reforming and isomerization units of the Tehran refinery. There are also plans to construct a lubricants plant in the northwestern city of Tabriz, which already is the site of an oil refinery. The plant, which would take four years to complete, would produce about 1.4 million tons of products annually. The excess of the products would be exported to neighboring countries. 
Table 2: Summary of Iran's Petroleum Product Consumption, 1972-93

thousand barrels per day

\begin{tabular}{|c|c|c|c|c|c|c|c|c|c|c|c|c|c|c|c|c|c|c|c|c|c|c|}
\hline & 1972 & 1973 & 1974 & 1975 & 1976 & 1977 & 1978 & 1979 & 1980 & 1981 & 1982 & 1983 & 1984 & 1985 & 1986 & 1987 & 1988 & 1989 & 1990 & 1991 & 1992 & 1993* \\
\hline $\begin{array}{l}\text { NGL/LPG/ } \\
\text { Ethane }\end{array}$ & 11.3 & 14.3 & 13.5 & 14.3 & 11.4 & 15.4 & 15.7 & 18.2 & 17.2 & 17.4 & 16.9 & 16.8 & 27.5 & 27.0 & 23.8 & 23.5 & 26.3 & 41.0 & 43.5 & 50.8 & 48.2 & $\mathrm{n} / \mathrm{a}$ \\
\hline Naphtha & 9.3 & 8.1 & 15.7 & 22.6 & 14.1 & 1.3 & $\ldots$ & $\ldots$ & $\ldots$ & $\ldots$ & $\ldots$ & $\ldots$ & $\ldots$ & $\ldots$ & $\ldots$ & $\ldots$ & $\ldots$ & $\ldots$ & $\ldots$ & $\ldots$ & & $\mathbf{n} / \mathbf{a}$ \\
\hline Gasoline & 35.8 & 43.3 & 51.1 & 64.3 & 66.7 & 81.0 & 88.1 & 100.1 & 83.8 & 75.1 & 78.7 & 102.3 & 110.7 & 102.7 & 103.9 & 110.7 & 109.8 & 127.4 & 142.0 & 158.9 & 164.3 & $\mathbf{n} / \mathbf{a}$ \\
\hline Jet Fuel & 17.6 & 18.3 & 22.7 & 23.8 & 23.5 & 28.1 & 25.9 & 19.4 & 14.6 & 9.0 & 9.7 & 8.3 & 12.3 & 13.1 & 10.8 & 11.6 & 9.3 & 9.1 & 17.2 & 24.3 & 26.0 & $\mathrm{n} / \mathrm{a}$ \\
\hline Kerosene & 36.2 & 49.2 & 55.6 & 69.7 & 88.9 & 92.2 & 100.5 & 124.7 & 96.3 & 90.1 & 102.1 & 133.4 & 136.4 & 143.2 & 101.4 & 121.6 & 119.9 & 109.0 & 112.4 & 126.7 & 128.1 & $\mathrm{n} / \mathrm{a}$ \\
\hline Diesel & 62.7 & 80.7 & 90.0 & 109.8 & 133.0 & 151.5 & 157.6 & 161.3 & 159.8 & 173.3 & 191.8 & 226.8 & 253.0 & 236.2 & 272.1 & 291.5 & 288.1 & 300.8 & 330.0 & 351.9 & 357.7 & $\mathbf{n} / \mathbf{a}$ \\
\hline Resid & 31.3 & 40.5 & 44.8 & 55.1 & 80.2 & 77.4 & 81.8 & 105.4 & 108.7 & 138.3 & 103.1 & 98.1 & 164.3 & 184.0 & 224.4 & 216.7 & 221.9 & 226.3 & 217.1 & 217.1 & 226.8 & $\mathrm{n} / \mathbf{a}$ \\
\hline Other & 12.1 & 14.7 & 15.5 & 22.9 & 18.4 & 25.8 & 25.1 & 23.0 & 25.5 & 23.7 & 25.6 & 38.4 & 26.8 & 28.4 & 39.9 & 43.8 & 47.3 & 45.5 & 57.5 & 63.3 & 64.1 & $\mathrm{n} / \mathbf{a}$ \\
\hline Refinery Fuel & 27.7 & 29.3 & 31.5 & 34.3 & 34.0 & 40.2 & 37.3 & 39.5 & 36.7 & 28.1 & 27.6 & 27.8 & 33.7 & 35.4 & 51.8 & 40.5 & 38.3 & 43.6 & 43.8 & 40.1 & 40.0 & $\mathrm{n} / \mathrm{a}$ \\
\hline Sub-Total & 244.0 & 298.4 & 340.3 & 416.8 & 470.2 & 513.0 & 532.0 & 591.6 & 542.7 & 555.0 & 555.5 & 652.1 & 764.8 & 788.0 & 828.0 & 860.0 & 860.9 & 902.5 & 963.6 & 1033.3 & 1055.2 & $n / a$ \\
\hline Bunkers & 118.7 & 128.2 & 116.8 & 105.6 & 78.3 & 73.2 & 62.9 & 47.4 & 29.1 & 19.3 & 29.4 & 31.6 & 31.4 & 30.7 & 29.6 & 25.2 & 28.0 & 40.3 & 49.3 & 49.3 & 27.8 & $\mathrm{n} / \mathrm{a}$ \\
\hline Total & 362.7 & 426.6 & 457.1 & 522.5 & 548.5 & 586.2 & 594.9 & 639.1 & 571.8 & 574.3 & 584.9 & 683.7 & 796.1 & 818.7 & 857.6 & 885.1 & 888.8 & 942.8 & 1012.9 & 1082.6 & 1083.0 & 1169.6 \\
\hline
\end{tabular}

- Estimates

Source: IEA Energy Statistics and Balances of Non-OECD Countries, 1991-92. 


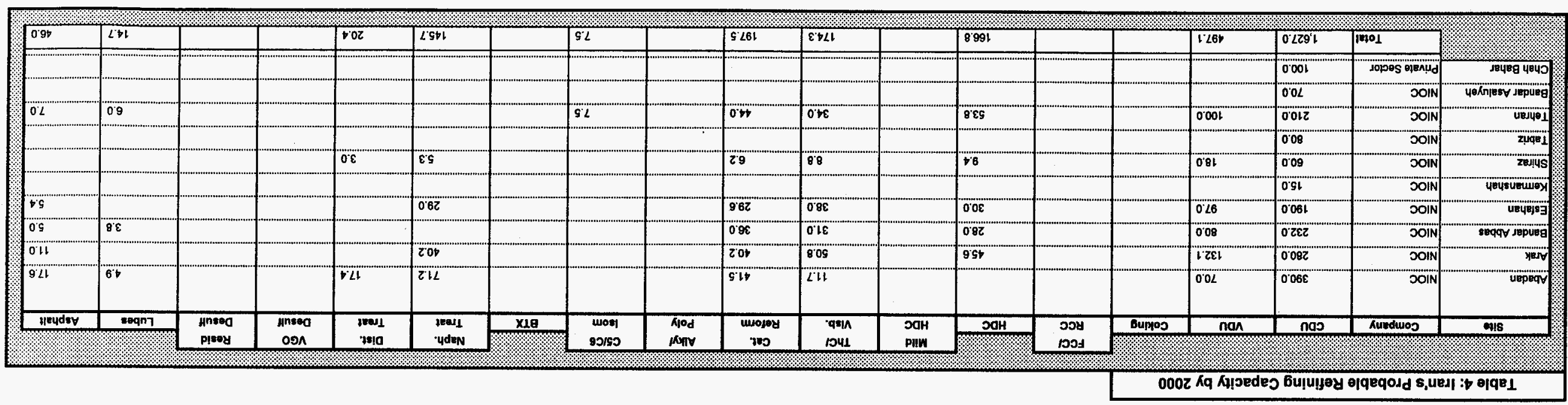

\begin{tabular}{|c|c|c|c|c|c|c|c|c|c|c|c|c|c|c|c|c|c|c|}
\hline 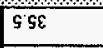 & $60 \mathrm{O}$ & & & roz & 99821 & & & & iszi & 6211 & & 0.911 & & & 0158 & 10986 & 1001 & \\
\hline \multirow[t]{4}{*}{02} & 09 & & & & & & & & 082 & ore & &  & & & 0.001 & 0012 & DoाN & verय1) \\
\hline & & & & & & & & & & & & & & & 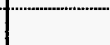 & 008 & 2011 &  \\
\hline & & & & $0 \varepsilon$ & 89 & & & & 29 & 88 & & 18 & & & 081 & 009 & 201N & 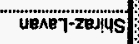 \\
\hline & & & & & & & & & & & & & & & & Ost & 2011 & 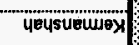 \\
\hline to & & & & & 0.62 & & & & 962 & $\sigma^{\circ} 8 \varepsilon$ & & 008 & & & 026 & 0.061 & 2011 & 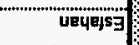 \\
\hline sq & & & & & $10 z$ & & & & 1.02 & Dss & & 822 & & & 099 & 0.011 & oOाN & Txend \\
\hline 941 & 67 & & &  & $2+2$ & & & & sit & $2 \pi$ & & & & & 002 & 0062 & नoli & ueppoval \\
\hline गाleydsy & seqn7 & unssa & 4nsea & jeav1 & zoou1 & $x \perp 1$ & wos! & Apod & twojory & वश/ & $\mathrm{SOH}$ & $\mathrm{SOH}$ & 20y & Bulyos & nan & nas & Ruedurog & 9.18 \\
\hline & & plsou & oפת & 7910 & Ydd $\mathrm{N}$ & & 90150 & 1 & 100 & 1041 & PlIN & & 100: & & & & & \\
\hline
\end{tabular}


By the year 2000, two new major refineries are planned to come on stream: Arak II and Bandar Abbas. Arak II, which is a twin of the Arak I plant, will have a processing capacity of 140 thousand $b / d$, and will use heavy crude from Dezful as feedstock. The 232 thousand b/d Bandar Abbas refinery will have a hydrocracking/visbreaking/reforming configuration, but an expansion of its capacity in the not so remote future seems inevitable, since compared with its distillation capacity, its cracking and reforming units are relatively undersized.

Other expansion plans for the year 2000 include a 70 thousand b/d refinery in Bandar Asaluyeh, some 560 miles south of Tehran, and also, a 100 thousand b/d refinery that would be financed by the private sector. This project, which is still under negotiation with the private sector, would be located in the free trade zone of Chah Bahar. The Bandar Asaluyeh refinery, one of the top priority projects to have received approval for external borrowing in the 1994-95 budget, was originally planned to be built in Bandar Taheri. Iran has invited bids from international investors, but given Iran's debt situation, foreign contractors have shown little interest so far.

Although these additions in production capacity will seemingly bring Iran closer to its much wanted state of self-sufficiency, the constantly increasing level of domestic demand will make it very difficult for the country actually to achieve that goal (Figure 10). Presently, Iran's product exports are limited to fuel oil and naphtha (Figure 11), while it imports large volumes of middle distillates. In the year that ends in March 1995, Iran is expected to import as much as 190 thousand b/d of products. As a matter of fact, it seems unlikely that Iran would be able to reduce its imports significantly by the turn of the century, and even its exports of naphtha and fuel oil are expected to shrink after 2000 (Figures 12 and 13). Just to sustain the same level of imports and exports as today, it needs not only to accomplish its expansion plans for the next five years, but also to maintain again the same growth rate for the following five-year period to the year 2005 . As can be seen in Figures 12 and 13, Iran will continue to be a major importer of middle distillates. If consumption of oil products in the country continues its ascent at the current rates, Iran could cease to be an oil exporter within a period as short as 15 years. Thus Iran's role in the international market is expected to be determined not by its level of product exports, but by the volume of products it will absorb from the Persian Gulf market. 


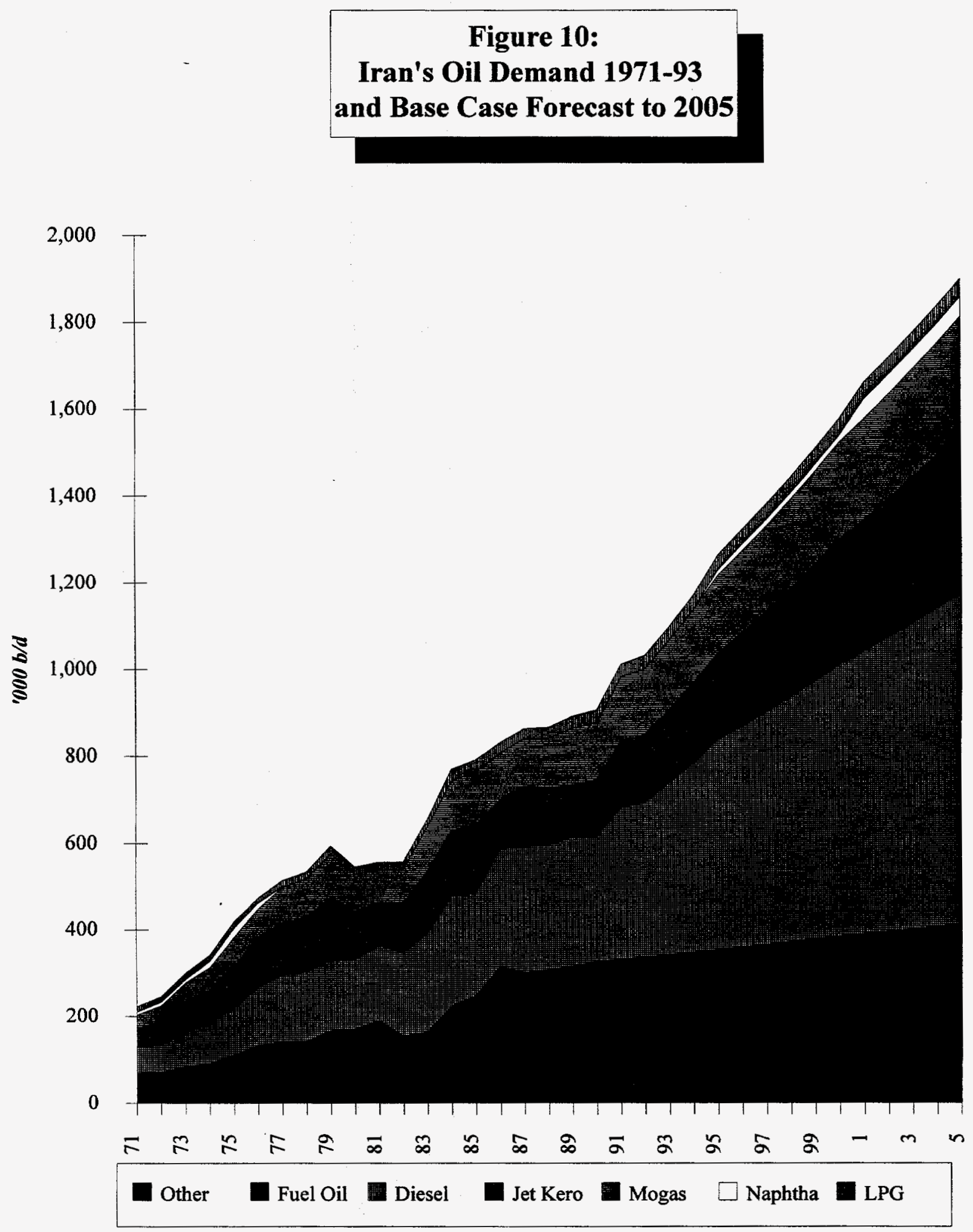




\section{Figure 11:}

Iran's Refined Product Exports, 1989-2005

(based on current expansion plans)

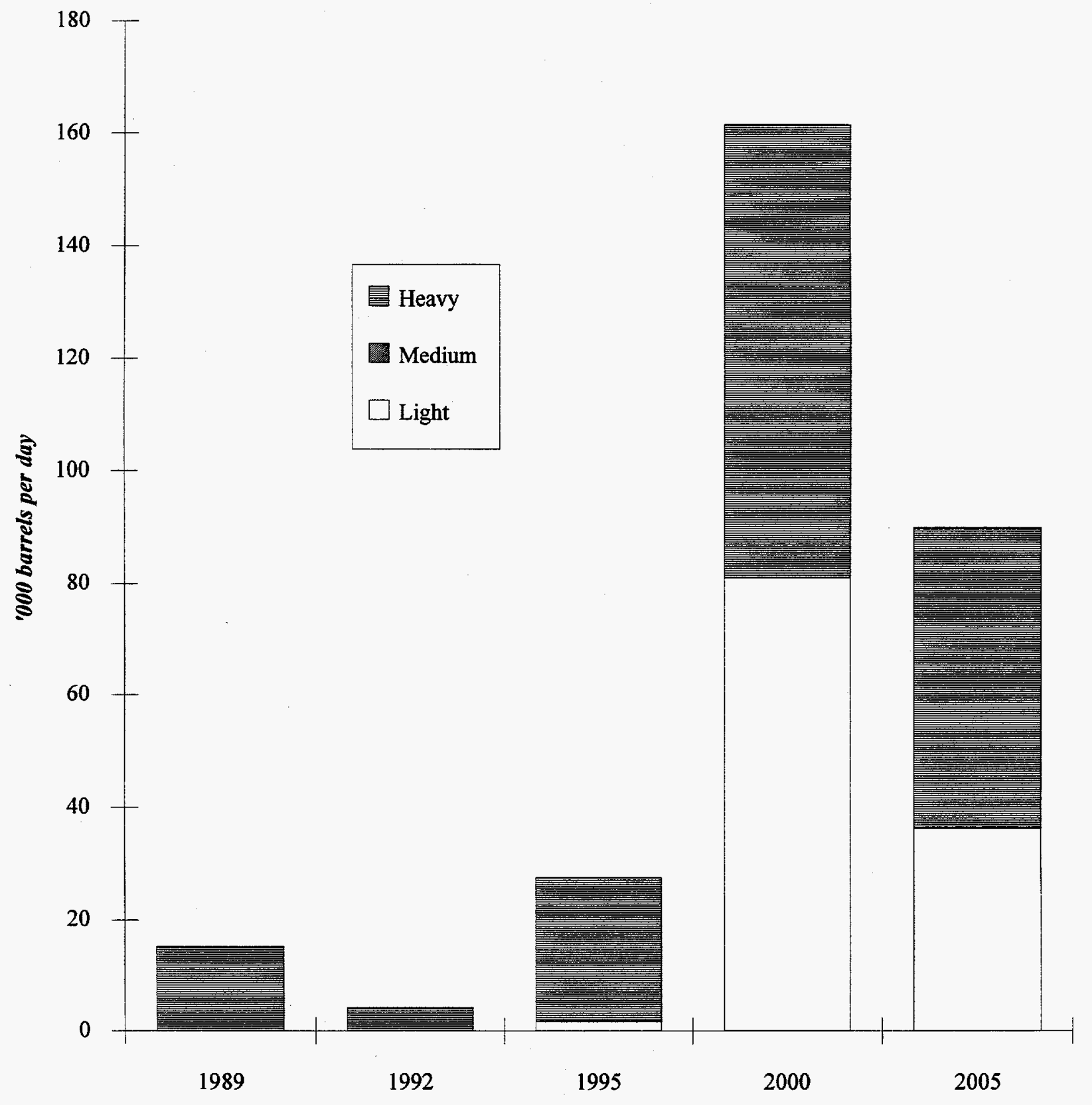


Figure 12: Base Case Projected Petroleum Product Balance, 2000




Figure 13: Base Case Projected Petroleum Product Balance, 2005

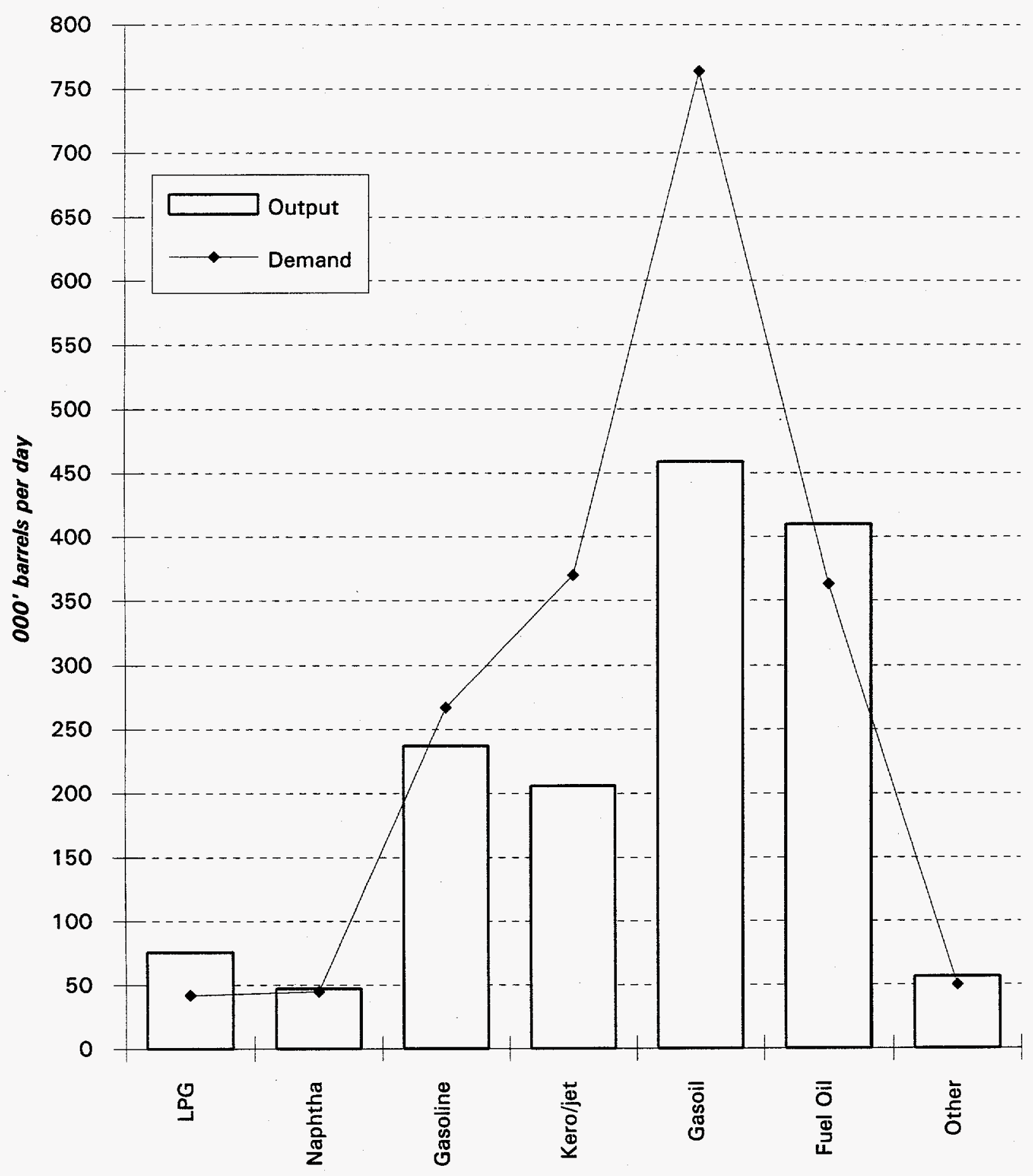




\section{II.3. Iran's Oil Export Destinations}

Buyers of Iranian crudes are widely varied, ranging from Turkey to North Korea, Brazil, Italy, and Sudan. Iranian crude-exports destinations have evolved somewhat in recent years. In comparison with before the revolution, a much larger portion of Iranian crudes is delivered to the Far East. Figure 14 shows the percentage of crude sales east and west of Suez in 1993. Sales to the Far East reached 1.2 million b/d (56\% of the total), while only 44 percent (or 972 thousand b/d) of the Iranian crude sales went to the west of Suez. Trade with Asia, and with Japan in particular, has increased substantially, to the extent that in May 1994, Iran was the third largest exporter of crude to Japan with 311 thousand $b / d$, after the UAE and Saudi Arabia. Iran has offered investment opportunities to the Japanese firms during its Second Five-Year Plan, in return for which it promises to supply most of the Japanese oil and gas needs. Whether the Japanese businessmen find investment in the Iranian manufacturing industry attractive enough to induce them to provide financing is yet to be seen.

Table 5 shows all the liftings of Iranian crudes in 1993. It is worth noting that Brazil which had traditionally been a major buyer of Iranian crude, reduced its crude liftings by nearly 80 percent in mid-1993, for pricing reasons. Total sales of Iranian crude to foreign companies reached nearly 2.2 million b/d in 1993, with Exxon the largest buyer with a total of 193 million b/d. Japan's Tomen occupied the second place with 159 thousand b/d, followed by BP and Marc Rich, with 123 and 109 thousand b/d, respectively. For 1994, the breakdown between eastward and westward sales has not changed significantly, with 46 percent, or 1.2 million $\mathrm{b} / \mathrm{d}$, of total sales to the western countries, and the remaining 54 percent, or about 1.4 million b/d, going to the Far East (Figure 15).

New contracts for 1994 (Table 6) include an exchange deal with Croatia, an estimated 30 thousand b/d to Bulgaria, and roughly 180 thousand b/d sold to South Africa's five major refiners. The volumes for the Croatian contract have not yet been specified, but the deliveries are scheduled to start before the end of 1994. In 1992, Iran supplied Croatia with an average of $34,000 \mathrm{~b} / \mathrm{d}$. As for South Africa, Iran's latest term deal with the two major refiners there - BP and Shell - brings its total supply to that country up to nearly 180 thousand $b / d$, or almost half of its 350 thousand b/d crude 


\section{Figure 14: Iran's Crude Sales, 1993}

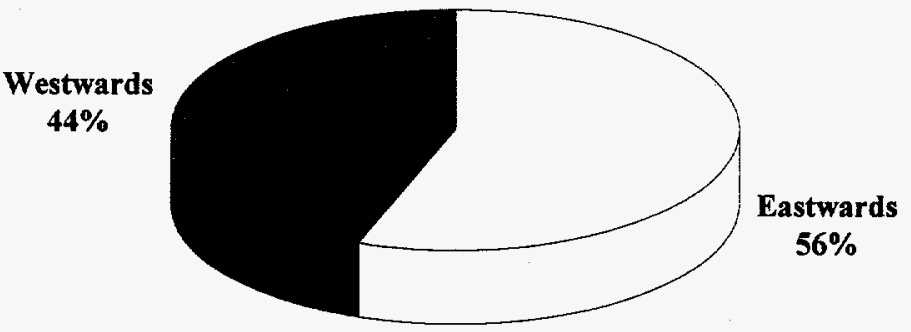

\section{Table 5: Iran's Crude Liftings, 1993}

thousand barrels per day

\begin{tabular}{|c|c|c|c|c|}
\hline Exxon & 193 & Indian Oil & 43 & Elf \\
\hline Tomen & 159 & Hyundai & 53 & Pedestal \\
\hline $\mathrm{BP}$ & 123 & Total & 42 & Vitol \\
\hline Marc Rich & 109 & Motor Oil Hellas & 37 & Mitsubishi oil \\
\hline Tupras (Turkey) & 96 & Kyung In & 39 & Petronas \\
\hline Phibro (Derby) & 89 & Marubeni & 30 & Elpida (Sudan) \\
\hline Shell & 89 & CPC (Taiwan) & 30 & OMV (Austria) \\
\hline Bay Oil & 88 & Mitsubishi Corp. & 27 & Iritechna \\
\hline Coastal & 86 & Sumitomo & 26 & Petrolexport \\
\hline Petrofina & 80 & Sonatrach & 25 & Thailand \\
\hline Caltex & 70 & Showa-Shell & 25 & OK Petroleum \\
\hline Socap & 70 & Itochu & 23 & North Korea \\
\hline Yukong & 67 & Kanematsu & 22 & Neste \\
\hline Texaco & 58 & PNOC (Philippines) & 22 & Gotco \\
\hline Idemitsu & 51 & Mitsui & 21 & Ceylon \\
\hline Petrobras & 49 & Pakistan & 19 & Agip \\
\hline Mobil Oil & 49 & Cargill & 16 & \\
\hline Cosmo & 47 & Sri Lanka & 15 & \\
\hline
\end{tabular}

Total: 2,193 


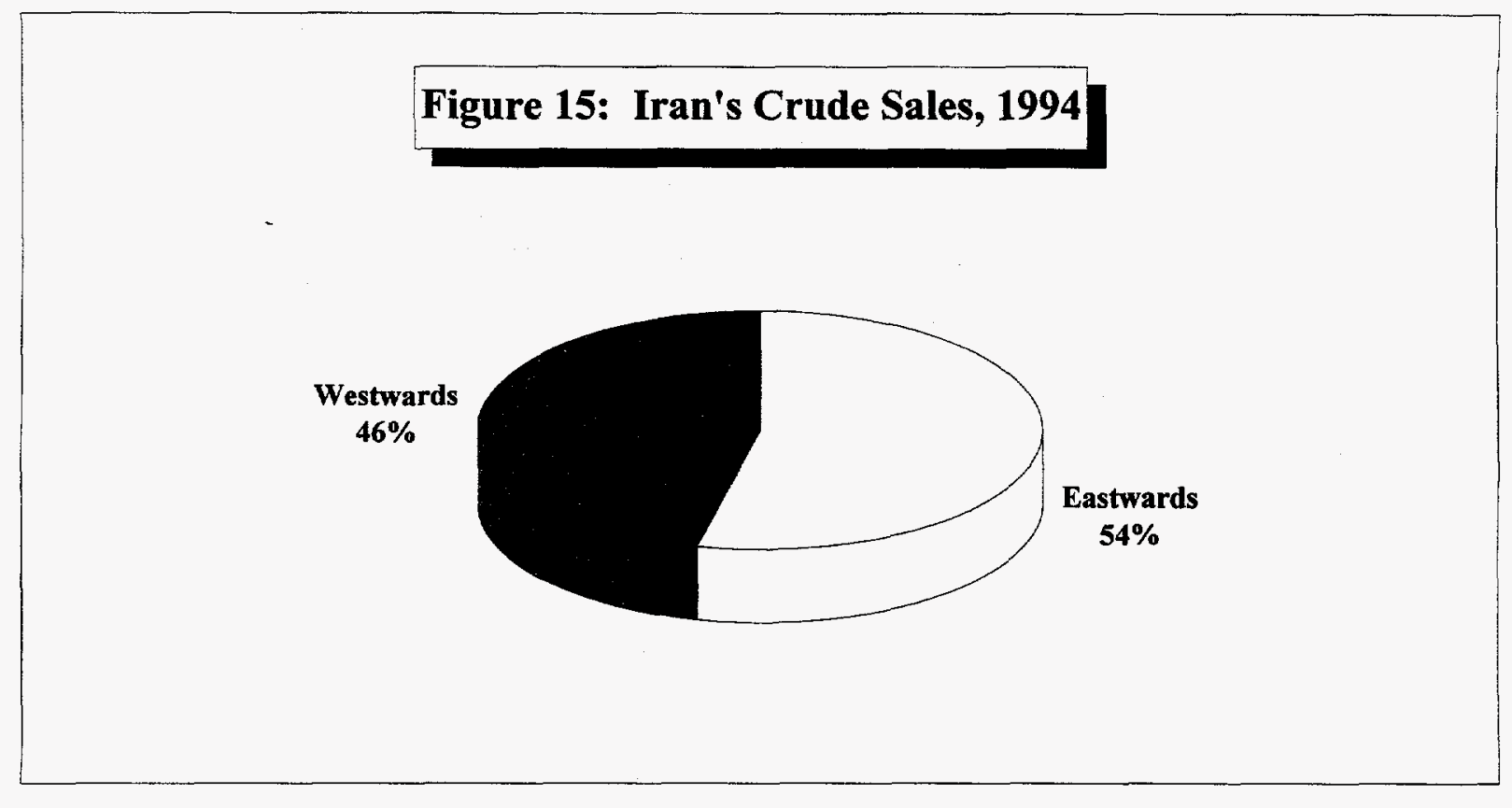

\begin{tabular}{|c|c|c|c|c|c|}
\hline \multicolumn{6}{|c|}{$\begin{array}{l}\text { Table 6: Iran's Crude Liftings, } 1994 \\
\text { thousand barrels per day }\end{array}$} \\
\hline Exxon & 250 & CPC (Taiwan) & 60 & Showa-Shell & 30 \\
\hline Tomen & 150 & Petronas & 60 & Itochu & 30 \\
\hline BP & 150 & Iritechna & 55 & Total & 25 \\
\hline Shell & 130 & Mobil Oil & 50 & Kyung In & 20 \\
\hline Bay Oil & 98 & Ceich (Poland) & 50 & PNOC (Philippines) & 20 \\
\hline Coastal & 120 & Caltex & 89 & Pakistan & 22 \\
\hline Tupras (Turkey) & 94 & Motor Oil Hellas & 40 & Ceylon & 19 \\
\hline South Africa & 100 & Sumitomo & 40 & IPG (Kuwait) & 15 \\
\hline Petrofina & 86 & Kanematsu & 40 & Sri Lanka & 15 \\
\hline Phibro (Derby) & 64 & Mitsui & 40 & Thailand & 15 \\
\hline Yukong & 70 & Marc Rich & 36 & Chevron & 7 \\
\hline Idemitsu & 70 & Petrobras & 30 & Portugal & 7 \\
\hline Elf & 70 & Cosmo & 30 & Croatia & $\mathrm{n} / \mathrm{a}$ \\
\hline Texaco & 60 & Marubeni & 30 & Bulgaria & $\mathrm{n} / \mathrm{a}$ \\
\hline Indian Oil & 60 & Mitsubishi Corp. & 30 & & \\
\hline Hyundai & 60 & Sonatrach & 30 & & \\
\hline
\end{tabular}


market. Once again in 1994, Exxon is the single largest buyer of Iranian crude with 250 thousand b/d, followed by Tomen and BP (150 thousand b/d each), and Shell in fourth place with 130 thousand b/d. In contrast with 1993, Marc Rich has reduced its liftings drastically to only 36 thousand $b / d$.

Asian contracts are on an annual basis and are priced quarterly, whereas the crude sold west of Suez follows a much less rigid structure. Here, the volumes can vary within a range according to the buyer's needs. The crude is usually sold from the terminal on Kharg Island in the Persian Gulf. Depending on the buyer's requirements, it can also be sold from Sidi Kerir, located at the end of the Egyptian Sumed pipeline, in the Mediterranean. Iran has also limited storage facilities in Rotterdam (the Netherlands) and Le Havre (northern France).

Iran's crude exports capacity saw a big boost in October 1994 with the completion of the repair and reconstruction work at its Kharg terminal. The work was carried out by the French construction company ETPM and South Korea's Daewoo. The terminal, which was extensively damaged during the Iran-Iraq war, will have an additional capacity of 4 million b/d. All of Iran's onshore and one offshore (Foroozan blend) crudes are exported via this terminal. The remaining offshore exports take place at Sirri and Lavan terminals in the southern area of the Persian Gulf. The other two terminals - Ras Bahregan (onshore) and Cyrus (offshore) - are not in use at present. With the coming into operation of the Kharg terminal, Iran's total export capacity will reach 7 million b/d, which is substantially higher than its actual exports volume of an average of 2.5 million $\mathrm{b} / \mathrm{d}$, and more than double its Opec quota. The volume of the crude exported from the onshore and offshore fields during 1993 is shown in Table 7. In 1993, Iran exported 2.6 million $\mathrm{b} / \mathrm{d}$ of onshore crude, versus 113 thousand $\mathrm{b} / \mathrm{d}$ of crude from its offshore fields. This was slightly higher than the 1992 crude exports of a total of 2.52 million b/d, with 2.45 million $\mathrm{b} / \mathrm{d}$ from the onshore fields, and the remaining 73 thousand $\mathrm{b} / \mathrm{d}$ from the fields located offshore. In Figure 16, we can see a breakdown of Iran's exported crudes by type. Iranian Heavy has the largest proportion of the crude export mix with 55 percent, against 44 percent of Iranian Light. Offshore crudes have an aggregate share of 4 percent of the total crude exports. The value of Iran's oil exports for the year to March 1994 is estimated at over US\$14 billion. It is important to note here that with the recent policy adopted by Saudi Arabia to accentuate the production of Arab Light for financial reasons, the Iranian crude export mix has been modified to emphasize its heavy grade crude production and export. Thus, in the second quarter of 1994, the share of Iranian Heavy in 
Table 7: Iran's Crude Exports, 1993

thousand b/d

\begin{tabular}{|c|c|c|c|c|c|c|c|c|c|c|c|c|c|c|}
\hline & Jan & Feb & Mar & Apr & May & Jun & Jul & Aug & Sep & Oct & Nov & Dec & Year '93 & Year 92 \\
\hline \multicolumn{15}{|l|}{ Onshore Fields } \\
\hline Iranian Light & 1,265 & 1,166 & 1,170 & 1,092 & 1,194 & 1,252 & 1,205 & 1,115 & 1,098 & 1,232 & 850 & 1,015 & 1,139 & 1,100 \\
\hline Iranian Heavy & 1,459 & 1,662 & 1,616 & 1,554 & 1,604 & 1,502 & 1,482 & 1,277 & 1,551 & 1,429 & 1,401 & 1,509 & 1,504 & 1,352 \\
\hline Total Onshore Fields & 2,724 & 2,828 & 2,786 & 2,646 & 2,798 & 2,754 & 2,687 & 2,392 & 2,649 & 2,661 & 2,251 & 2,524 & 2,643 & 2,452 \\
\hline
\end{tabular}

\section{Offshore Fields}

\begin{tabular}{|c|c|c|c|c|c|c|c|c|c|c|c|c|c|c|}
\hline Foroozan Blend & $\ldots$ & 79 & 32 & 62 & 15 & 14 & 38 & 46 & 36 & 39 & 19 & 31 & 34 & 24 \\
\hline Sirri & 48 & 28 & 23 & 25 & 20 & 52 & 24 & $\ldots$ & 52 & 43 & 21 & 19 & 30 & 27 \\
\hline Lavan Blend & 18 & $\ldots$ & 49 & $\ldots$ & $\ldots$ & 21 & 21 & 37 & 21 & 20 & 197 & 198 & 49 & 22 \\
\hline Total Offshore Fields & 66 & 107 & 104 & 87 & 35 & 87 & 83 & 83 & 109 & 102. & 237 & 248 & 113 & 73 \\
\hline Total Exports & 2,790 & 2,935 & 2,890 & 2,733 & 2,833 & 2,841 & 2,770 & 2,475 & 2,758 & 2,763 & 2,488 & 2,772 & 2,758 & 2,525 \\
\hline
\end{tabular}

Source: Adopted from data reported in Middle East Economic Survey.

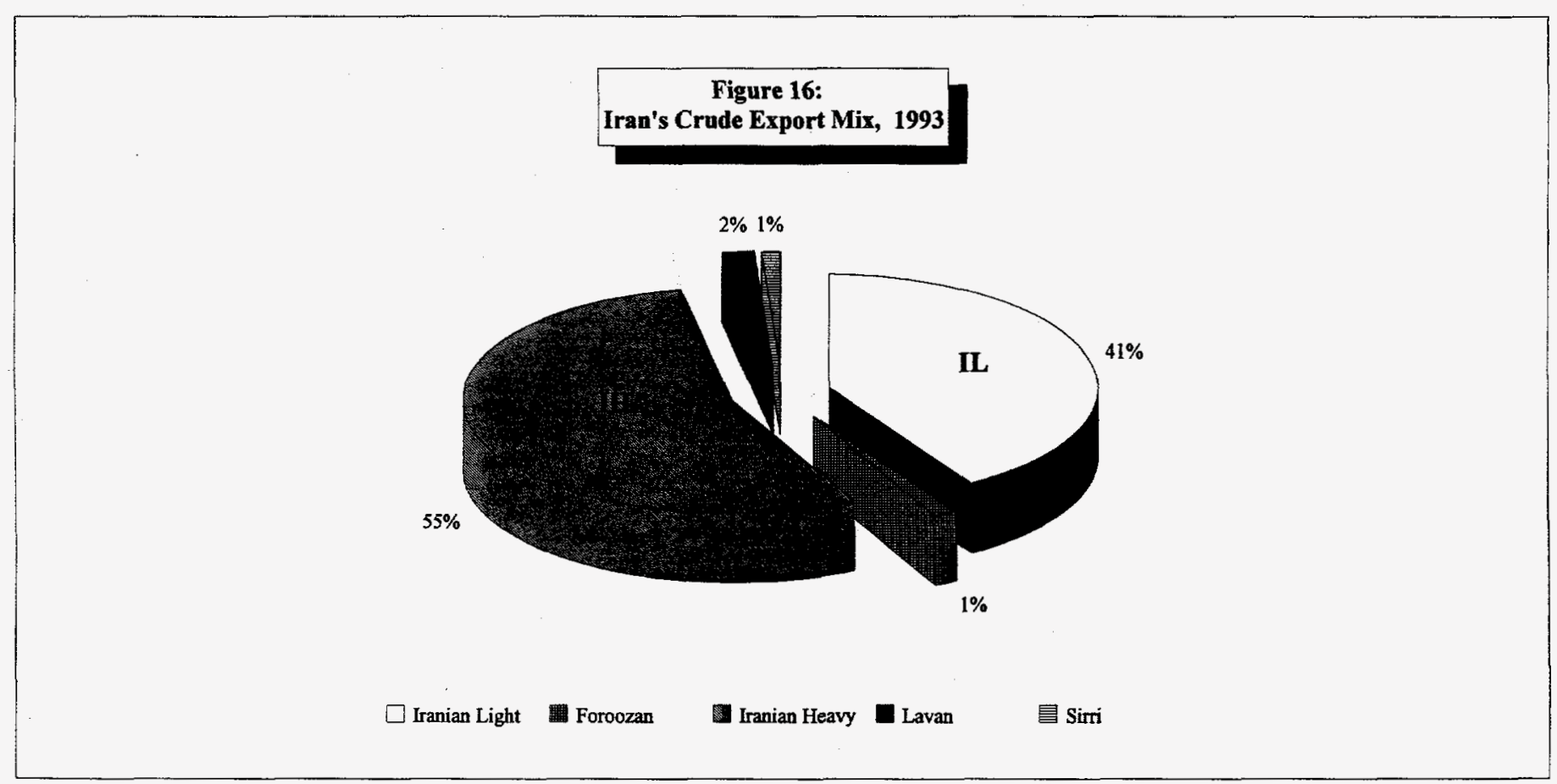


the export mix was raised to 58 percent while Iranian Light went down to 36 percent. Foroozan, Sirri, and Lavan blend had a slight increase in share up to 6 percent of total exports.

Another interesting feature of the Iranian crude exports is that the first place is occupied by Exxon, a U.S. oil company. Over the past couple of years, and for the first time since before the Islamic revolution, U.S. firms have once again become some of the largest buyers of Iranian crude. This may appear particularly odd at first glance, taking into account the hostile atmosphere that reigns between the two countries, and the ban that the U.S. government has imposed on all imports from Iran into the United States. Even though these companies cannot use the crude domestically, they still use it for resale outside the United States. U.S. firms bought approximately 460 thousand b/d (21\% of the total) of Iranian crudes in 1993, followed closely by the Japanese volumes of 440 thousand $\mathrm{b} / \mathrm{d}$ ( $20 \%$ of the total). All European companies combined purchased roughly 597 thousand $\mathrm{b} / \mathrm{d}(27 \%$ of the total) of crude from Iran. The value of Iranian crude liftings by U.S. oil companies in 1993 is estimated at US\$3.6 billion. Figures 17 and 18 show the growing importance of the U.S. buyers of Iranian crudes. In 1994, crude sales to U.S. firms are expected to increase substantially and reach 706 thousand $b / d$, larger than the volume sold to all European companies combined (595 thousand b/d). Japanese companies remain in 1994 the second single biggest buyers of crude from Iran, with 19 percent of the total sales volumes. Although their share in the total sales will decrease slightly from the 1993 levels, the volume of their liftings will go up to 490 thousand b/d.

\section{II.4. Emerging Relations with Central Asia}

Iran is also seeking to establish closer economic and trade links with its Central Asian neighbors. Several agreements for trade of crude and natural gas as well as industrial materials have been signed between Iran and the CIS republics. The largest trade agreement signed so far is for the annual export of about 14.5 million barrels of crude oil from Kazakhstan through Iranian outlets in the Persian Gulf. Iran has mentioned its plans to get involved in the exploration and development of the CIS fields, as well as the construction and revamping of refineries in the area.

Iran has been striving to promote closer economic and political bonds with the newly independent states in order not only to expand its natural gas and crude markets, but also to reduce its dependence on the Persian Gulf as the only outlet for its exports, by 
Figure 17: Iran's Crude Buyers, 1993

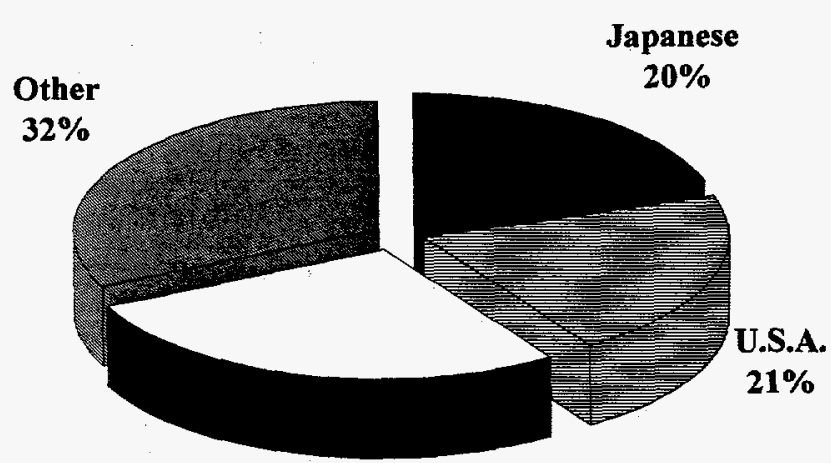

European

$27 \%$

Figure 18: Iran's Crude Buyers, 1994

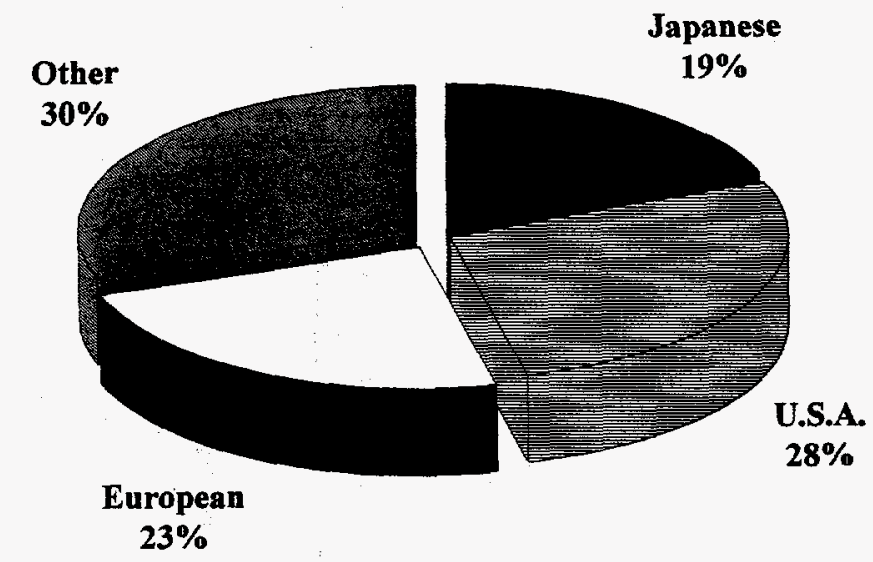


finding a new channel to Europe, through the Caucasus and Russia. This would also greatly enhance its geopolitical power in the region. During the First Five-Year Plan, although many promises were made, no single project moved beyond mere words. A notable example has been the role of Iran in providing an export route for the oil projects of the Caspian Sea. The crude extracted from the landlocked reserves of the Caspian can be a major source of supply for the European markets. However, all potential export routes are fraught with political instability. Russia is unlikely to be willing to export increasing volumes of the CIS crudes through its pipeline without extracting a major economic and political profit. At the same time, the other three potential routes for the pipeline - i.e. via Georgia, Armenia, or Iran - do not seem to be secure enough to attract financiers. A new issue here has been raised by Russia, which questions the control over the Caspian reserves. According to certain international treaties concluded between the USSR and Iran, the waters of the Caspian Sea beyond their ten-mile coastal zones are not to be used for any purpose other than fishing and shipping. In October 1993, however, Azerbaijan, Turkmenistan, and Kazakhstan proposed to share the waters of the Caspian as those of a lake, on the basis of the equidistance method. The Russian Committee on Geology and the use of the Subsoil, with the backing of the Ministry of Cooperation with the CIS states, has in turn proposed another method that would respect the existing international treaties signed with Iran, with the difference that it would extend the coastal zones to 12 miles. It would also declare the waters beyond the 12-mile limit "open waters" and, as such, subject to collective management by all Caspian states. Russia has also demanded that all resource development activities be banned in the fishing waters beyond the 12-mile delimitations.

There have been talks of a pipeline to export Turkmen gas to Europe via northern Iran. This is by far one of the most important projects between Iran and the CIS. It appears that work on the construction of the section going through Iran started immediately after an agreement was signed between the two countries on 24 August 1994. The construction of the pipeline, $1,450 \mathrm{~km}$ of which would pass through Iranian territory, would imply an investment of US\$2.9 billion. The pipeline would transport 15 million cubic meters initially, and later 30 million cubic meters per year of natural gas under a thirty-year concession. At the same time, a crude pipeline from Turkmenistan to the Tehran refinery was discussed, since the cost of building a similar pipeline from Iran's own oil fields to the refinery would be much higher. Under that scenario, Iran would exchange similar volumes of crude (around 6 million tons per year or nearly 120 thousand $b / d$ ) from 
its terminals in the Persian Gulf to pay for the Turkmen crude imports. The two countries have even looked into the possibility of setting up free trade zones and border markets.

Another protocol has also been signed between Iran and Kazakhstan to process Tengiz crude at the Tehran refinery as a temporary measure to reduce Kazakh dependence on Russia for its exports. The volume of the crude is initially going to be 2 million tons per year, increasing to 5 million at a later date. The agreement stipulates that Iranian crude of equivalent value will be exported on behalf of Kazakhstan from the Kharg Island terminal. There may also be a possibility of a swap agreement between Azerbaijan and Iran, whereby about 80 thousand b/d of crude would go to Iran's Tabriz refinery, and equivalent volumes of Iranian crude would be exported from the Gulf.

It is a fact that after the collapse of the Soviet empire, Iran has strived to expand its relations with its northern neighbors. In doing so, it has been in competition with the other neighbors of the CIS, particularly Turkey. Iran, despite representing new roads and channels to lucrative markets of the outside world, has not succeeded as yet in attracting large scale joint projects. This is mainly for political reasons, reinforced by the U.S. position, which favors any new pipeline developments from Central Asia that go through Russia, since the United States deems the Russian routes to be more secure than those of either Iran or Iraq. It seems that for the time being the Central Asian republics are reluctant to show much eagerness in what Iran has to offer, given all the ideological and political weight that it carries with itself. At the same time, the U.S. policy of discouraging close economic cooperation between Central Asian countries and Iran has had a negative impact on the region's policies toward Iran. 


\section{Chapter III}

\section{Natural Gas and Petrochemicals}

Natural gas and petrochemical industries in Iran have been growing rapidly over the past few years. This growth is expected to continue into the next decade, enabling Iran to play a major role on the international scene.

\section{III.1. Natural Gas}

Iran's natural gas industry has developed rapidly over the past two decades. Iran's reserves of roughly 20 trillion cubic meter $(\mathrm{tcm})$ are the second largest in the world after the former Soviet Union. Most of Iran's gas reserves are located in the southern part of the country, onshore and offshore. The single largest gas field in Iran, the South Pars Gas Reservoir, is located offshore with proven reserves of nearly $3 \mathrm{tcm}$ of gas and 3-4 billion barrels of condensate. The second largest gas field is the North Pars, also located offshore with reserves of about $1.4 \mathrm{tcm}$ of dry sour gas with very little condensate. In December 1993, a new offshore gas field with estimated minimum recoverable reserves of $0.5 \mathrm{tcm}$ was discovered in the Persian Gulf.

Estimated quantities of as much as 20 billion cubic meters per year $(\mathrm{bcm} / \mathrm{y})$ are produced as associated gas during the production of crude. It is also estimated that some $8 \mathrm{bcm} / \mathrm{y}$ of this gas is still being flared, despite efforts to utilize it as a source of energy for domestic household and industrial use. Natural gas consumption in Iran is estimated to have grown by an average of 24 percent since 1979 .

Since the mid-1970s, Iran has carried out the construction of major gas infrastructure. The country now has one of the largest high-pressure gas transmission pipelines with diameters of up to 56 inches. Another $22,000 \mathrm{~km}$ medium-pressure pipeline constitutes the country's gas distribution network, which so far covers about 175 Iranian cities and towns. 
The development of the gas infrastructure was part of the First Five-Year Plan's goals to encourage the utilization of natural gas in order to make more oil available for export. The winter of 1993 marked a record in gas sales in Iran, with 107 million $\mathrm{cm} / \mathrm{d}$ being delivered to domestic users. Of that, the commercial sector consumed 70 million $\mathrm{cm} / \mathrm{d}, 1.5$ million $\mathrm{cm} / \mathrm{d}$ went to households, and the rest was used by industry and power stations. Total production was estimated at $44 \mathrm{bcm} / \mathrm{y}$; with the grid supply estimated at about $39 \mathrm{bcm} / \mathrm{y}$, a minimum of $5 \mathrm{bcm} / \mathrm{y}$ is assumed to have been used for secondary recovery projects in oil fields. Several gas reinjection projects were delayed because of the 1980-88 war. Decreasing pressure in several reservoirs, notably in the oil fields of Maroon, Karang, and Parsi, has been a major concern for the government. Since the end of the war, a few of these projects have been completed, but if Iran aims to fulfill its plans to increase crude output capacity to 4.5 million b/d, other such projects will be vital during the Second Five-Year Plan.

In the Second Five-Year Plan, there are also calls for the substitution of natural gas for other fuels for industry as well as residential purposes. According to the plan, the share of natural gas in the hydrocarbon energy supply of the country will increase to 41.5 percent from the current 33 percent. As much as 50.9 billion cubic meters $(\mathrm{bcm})$ would be available for domestic distribution in 1999, compared with the present volume of 29.2 bcm. This would ultimately be within the framework of a twenty-year gas plan, during which the government hopes to increase the production of natural gas to $310 \mathrm{bcm} / \mathrm{y}$, with $260 \mathrm{bcm} / \mathrm{y}$ for the domestic market, and about $5 \mathrm{bcm} / \mathrm{y}$ available for exports. Given the size of the Iranian gas reserves, these plans could be technically viable. The question that remains, however, is the financing of any such enterprise. In the meantime, serious cash shortage problems have indefinitely delayed the completion of the program to extend the natural gas network to twenty-two more cities during 1993-94. Plans to incorporate the two remaining districts of Tehran into the gridline by 20 March 1994 were also abandoned. The refusal of the Parliament to endorse the fuel price increases is deemed to be the major cause, and if funds are not allocated otherwise by the government, the financing of many such projects will become questionable.

Several development projects are currently under study in Iran. One is the development of the North Pars gas field, located offshore in the Persian Gulf, approximately $150 \mathrm{~km}$ southeast of Bushehr port, and $15 \mathrm{~km}$ off the coast. A joint study by Shell and the National Iranian Oil Company (NIOC) was undertaken. The production capacity of this field's lean sour gas is estimated to be 123 million $\mathrm{cm} / \mathrm{d}$. Initial plans 
indicate that the first 33.6 million $\mathrm{cm} / \mathrm{d}$ will be used for reinjection into the oil reservoirs of the southern onshore oil fields of Gach Saran, Bibi Hakiemeh, and Binak. At a later stage, another 67.2 million $\mathrm{cm} / \mathrm{d}$ would go to the depleting Agha Jari field, for pressure maintenance purposes. Shell has been insisting on a production-sharing contract without much success. This has been the major obstacle in the development of the project. According to Iranian law, repayments can be only from the output of the reservoir that is being developed, in this case North Pars gas. The problem is that North Pars's lean dry gas does not provide much condensate. It seems, however, that Iran, sensing also the urgency to develop these fields, has become more flexible. NIOC has agreed to pay for the services of Shell in the form of condensate, but this is still not what Shell demands i.e., crude from the specific onshore fields where the gas will be reinjected. This is particularly important for Shell, since secure access to oil is absolutely vital to procure financing. This is the main hurdle preventing the two companies from reaching an agreement. The investment required is estimated by Shell at US\$1.2 billion for Phase I, and roughly US\$4 billion for the development of the second phase. Iran has nevertheless expressed its firm intentions to make a final decision on this issue before the end of 1994, and is said to have submitted its final proposals to Shell.

On the other hand, a letter of intent to a consortium led by the Italian company TPL for the development of South Pars was canceled due to financing difficulties in 1993. The management of the US\$1.7 billion project, which would involve the production of about 28 million $\mathrm{cm} / \mathrm{d}$ of natural gas and $50,000 \mathrm{~b} / \mathrm{d}$ of condensate, was then transferred to the Iranian Offshore Oil Company (IOOC). IOOC has expressed its intentions to break down the field into five or six blocks that could be developed individually. Finally, in August 1994, IOOC awarded the first phase of the South Pars project to a newly formed company sponsored by NIOC: the Petroleum Development and Engineering Company (Petco), headed by Mostafa Khoee, the former managing director of the IOOC. The contract of a value of $\$ 900$ million involves the production of about $1 \mathrm{bcf} / \mathrm{d}$ of natural gas and 40 thousand $b / d$ of condensates. Petco is said to intend to rely on foreign exchange for only half of the cost of the project. Bids for the management of the project have already been received from international firms. There were also talks of some form of cooperation with Qatar for the development of these fields, since South Pars is an extension of Qatar's North Dome field. Parallel to these talks, the Iran Gas Europe Group formed by NIOC, Gaz de France, Austria's OMV, Germany's Ruhrgas, Spanish Enagas, the Czech Republic's Cesky Plynarevsky Podnik, and Slovakia's Plynarevsky Priemysel, is to launch an international tender for the development of a 100-tcf gas field. The field is 
assumed to be South Pars, and the tender calls for separate feasibility studies on export pipeline routes and on the viability of an LNG project that would become operational after 2010.

Separately, there have been talks of a proposed trunkline loop. The loop would link the Middle East reserves to a pipeline system that would distribute the gas, first within the region, and then on to Asia and Europe. Several of the members of the Iran Gas Europe Group are likewise involved in this project. The loop, with a hefty price tag of US $\$ 10$ billion, would gather all the gas in the Gulf via two pipelines between Doha and Kangan, linking the UAE and Iran. They would connect to two LNG terminals in Chah Bahar (southern Iran) and Bimmah (UAE), from which the Asian market would be supplied. At the other end, the pipeline would go from Kangan into Turkey, where it would join the Central European system that runs through Bulgaria, Rumania, and Austria. This project is still in its first feasibility study stage, and the more detailed phase of the study, covering distribution and collection systems, is planned to start in the last quarter of 1994. The completion date is again after 2010.

A feasibility study is currently under way for a transoceanic pipeline from the island of Qeshm to Gujarat, in western India. The pipeline would cross the Pakistani continental shelf and open the way for Iranian gas exports to other Asian countries. The cost of this pipeline is estimated to reach US\$5 billion. The project is competing with a similar proposal for a subsea gasline from Oman to India, which would transport 50 million $\mathrm{cm} / \mathrm{d}$ of gas to Gujarat. A conditional contract has already been signed between Oman and India. However, some important issues such as pricing, contract duration, delivery points, and minimum delivery volumes have not yet been agreed upon. The Indian government has shown its agreement in principle to a gas supply project, although the signature of a long-term contract has been deferred, awaiting the detailed feasibility study results, due to be completed in December 1994.

In June 1994, Arco discussed with Iran the development of an offshore gas field near Bandar Abbas, which would potentially provide the gas for the Iran-India pipeline project. The first feasibility study for this project will be completed by the end of 1994 .

Iran has signed an agreement with Azerbaijan to export 10 million cubic meters per year of natural gas to the autonomous Azeri region of Nakhichevan. Nakhichevan is separated from the rest of Azerbaijan by Armenia, and therefore, a new pipeline will be needed to transport the gas. According to the agreement, in return Nakhichevan will 
supply 60,000 tons of oil products, including gasoil and kerosene, to the Iranian region of East Azerbaijan.

Iran has signed a similar agreement with Armenia to build a $150 \mathrm{~km}$ pipeline for the delivery of 3 million $\mathrm{cm} / \mathrm{d}$ of natural gas. The total cost is estimated to reach US\$75 million. Iran would pay for its portion with gas, but Armenia needs to find financing for its part. The pipeline would start in Tabriz, in northwestern Iran, across the Armenian border, and extend to Kajaran, where it would link up with an existing gridline that has become nonoperational because of Armenia's conflict with Azerbaijan

Another export possibility for Iran is the proposed supply of $1 \mathrm{bcm} / \mathrm{y}$ of natural gas to Georgia. An existing pipeline, which was previously used to carry gas from Iran to Azerbaijan, would be used for this delivery. Iran stopped pumping gas to Azerbaijan in 1993, when Baku failed to pay for the deliveries.

\subsection{Petrochemicals}

The petrochemical industry is a sector in Iran that is considered to have great potential as a major source of non-oil export revenue. Iran's vast hydrocarbon resources constitute a comparative advantage that can play an important role in the development of this sector of industry. Owing to the fact that most of the petrochemical plants were located in the war zone area, production was deeply affected, and in some cases totally suspended during the eight-year war with Iraq. One of the major goals of the First FiveYear Plan in 1989 was to revive and expand this industry, with the final aim of reaching a state of self-sufficiency in fertilizers, plastics, and chemicals, and even exporting the surplus of some of these products. Major efforts have been made to achieve these goals, although not all the projects outlined in the first development plan have been accomplished. Nevertheless, the total annual output rose from 884,000 tons in 1989 to 5.5 million tons in the year ending in March 1993, and 1.4 million tons of the latter year's output was fertilizer. The total output is expected to reach 8 million tons per year by March 1995, ten times higher than before the start-up of the first economic reform. Some of the products produced during the year that ended in March 1993 included carbon black, methanol, soda ash, PVC, and diammonium phosphate. Also, some LPG was produced in the Bandar Imam complex and some aromatics in Esfahan. Iran also exported a total volume of 1 million tons of petrochemical products during the same period. The value of the products, which included methanol, sulfur, ammonia, and LPG, is estimated at about 
US\$130 million. Iran's earnings from the export of eleven different petrochemical products reached nearly US\$195 million for the fiscal year that ended in March 1994, and they are estimated at US\$300 million for the fiscal year ending in March 1995. Table 8 shows the total petrochemical output as of March 1994. LPG and fertilizers have the highest output, with 1.2 and 1.5 million tons per annum.

This rise in output was achieved through the expansion of some existing plants, at the same time as the implementation of new projects such as the Bandar Imam petrochemical complex (producing LPG), the Shiraz methanol plant, the Esfahan aromatics project, and the diammonium phosphate fertilizer plant at the Razi petrochemical complex. The phase II of the Bandar Imam complex came on stream on 1 August 1994, bringing the plant's total production capacity up to 3 million tons from 1 million tons per year. Phase III of this project is due to be completed in September 1996. The construction of the Bandar Imam complex was initially started in 1973, by a JapaneseIranian joint venture called the Iran Japan Petrochemical Company (IJPC). The complex was almost completed in 1980 when the Iran-Iraq war started. . The plant sustained extensive damage during the war. In 1984, the Japanese side, which was made up of a consortium of Mitsui Group companies, decided to withdraw from the project, paying heavy compensation fees to Iran. In 1990, after the start up of the first phase of the complex, Iran awarded the reconstruction contract to Krupp Koppers of Germany and Lummus Crest of the Netherlands. Technip of France was awarded the management of the project, following which some $\$ 850$ million of credit was made available to the project by the French financial institutions.

Other projects due for completion in the next couple of years include the second phase of the Arak petrochemical complex in 1995, the Khorasan plant producing 330 thousand tons of ammonia, and nearly 500 thousand tons of urea, also in 1995, and the Tabriz complex in 1996.

It is estimated that around 80 percent of the total petrochemical output is absorbed by the large domestic market, leaving only 20 percent of the production for exports. Given the growth expected in the domestic market, it seems unlikely that the share of exports will rise during the Second Five-Year Economic Plan. However, by the middle of the next decade, once all the projects planned for this period are completed, the volume available for exports may rise significantly. 


\begin{tabular}{lc}
\hline \multicolumn{1}{c}{ Table 8: NPC's Petrochemical Output, } \\
as of March 1994 \\
million tons per year \\
\hline LPG
\end{tabular}

(a) Includes LLPDE, HPDE, polypropylene, PVC, and polybutadiene.

(b) Includes soda ash and carbon black. 
Privatization projects in the First Five-Year Development Plan also covered the petrochemical industry. In addition to the main projects outlined above, eleven secondary projects were planned and were supposed be implemented during the period 1989-94. None of these has yet reached the implementation phase, although some are at the stage of financial arrangements and technology licensing negotiations with foreign partners. These secondary projects include a 660,000 tons/year methanol plant and a 500,000 tons/year methyl tertiary butyl ether (MTBE) plant. The prospects for attracting foreign investment seems brighter for these projects than for some of the other projects, thanks to the high demand in the international market for these products. These projects were to be launched by the private sector, with the help of the National Petrochemical Company (NPC). As an incentive, NPC had planned to allocate to these projects some foreign currency at a very cheap rate. After the reform of the exchange rate mechanism, however, such an allocation was no longer possible, and therefore most of these projects have been delayed. To compensate, NPC has decided to provide feedstock to the projects at rates 20 percent lower than the Persian Gulf f.o.b. prices, instead of the reduction of only 10 percent planned originally. Very recently, NPC once again raised the discount for feedstocks to 30 percent lower than the Persian Gulf f.o.b. prices. This makes the projects more viable, and NPC is hoping that the measure will help it to become more successful in attracting foreign investment. One project which seems to be well on its way with the participation of foreign companies is the US\$80 million polypropylene plant in the Tabriz petrochemical complex. The plant has a capacity of 50,000 tons/year and is scheduled to be completed at the end of 1994 with the participation of two German companies: BASF and Lurgi.

Currently foreign ownership in the Iranian petrochemical industry is limited to a maximum of 49 percent. The remaining 51 percent, or more, is always held by Iranian partners. It seems, however, that new proposals have been made to the Parliament in order to introduce new legislation that would allow 100 percent foreign ownership in the petrochemical ventures. In addition, there have been talks of the introduction of a new free trade zone for the petrochemical industry, with a view to facilitating foreign investment in this sector. Bandar Imam, a port city in the south, seems to be the most favored candidate for this purpose, given the number of complexes already established in this area, as well as the necessary infrastructure for expansion of current facilities and exports. 
In February 1994, the first phase of the Arak petrochemical complex was commissioned. The plant is designed to produce 200,000 tons of polymers and 1.07 million barrels of unleaded gasoline annually. The complex, once completed in the first quarter of 1295, is expected to bring in about US\$300 million of foreign currency through exports. At present, Iran's petrochemical output is not sufficient to satisfy the domestic demand, resulting in annual imports of about US\$2.5 billion.

Export orientation of the petrochemical industry is emphasized in the Second FiveYear Plan. The country aims to have a more active role and a greater share of the international market. Also, profit motivation and good rates of return on investment are part of the goals of this plan. Finally, as in other sectors of industry, privatization seems to be high on the agenda of the forthcoming economic development plan. The government thus stipulates that it intends to run and operate NPC as a private sector company, in order to make a profit. It would also like to invite local and foreign private interests to take part in new projects. There are already talks of several expansion projects, none of which have been approved by the Iranian Parliament as yet. These projects include a sixth olefin complex in Bandar Imam with a total output of over 600,000 tons/year, a 660,000 tons/year MTBE plant in Bandar Imam, a 500,000 per year olefin complex in Esfahan, and the expansion of the capacity at the Kharg methanol complex to 660,000 tons/year.

Once completed at the end of the Second Five-Year Economic Development Plan in the year 2000, these projects would raise the nameplate capacity to 13 million tons per year, resulting in an annual production level of around 10 million tons of petrochemical products. As such, Iran is heading toward becoming a key player in the Middle East petrochemical market, becoming the second largest producer after Saudi Arabia. 


\section{Chapter IV Conclusions}

Iran's aspirations to become a regional super-power have been greatly hindered by its major economic hardships. Not only is the country not getting any stronger, but also it continues to face new difficulties under the weight of its financial and economic burdens.

In spite of all the good intentions of the government, little progress has been made since the First Five-Year Economic Development Plan was launched more than five years ago. The country is still suffering from high inflation rates, unemployment, rapid population growth, escalating foreign debt, and on top of all that, lower oil revenues in a depressed world market, one thing over which it had, and has, no control.

Two key elements of the First Five-Year Plan were the dismantling of subsidies and the reform of the exchange rate mechanism - both of which suffered setbacks after a long battle with the regime's fundamentalists. Declining crude exports, owing to aging and deteriorating production facilities, have meant lower revenues, and therefore less hard currency. U.S. pressure, seeking political and economic containment of Iran, has made it more difficult for Iran to obtain foreign financing. The World Bank has canceled several loans that were to finance various energy-related projects in Iran. Although it has managed to reschedule a large portion of its debts, Iran has not been successful in finding new foreign credit.

Cheap fuel has led to major wastage of resources in the country. In addition, large sums of money that could be reinvested in the industry are being diverted to finance subsidies of all basic commodities in the country. The privatization process has stalled for reasons varying from the people's basic lack of trust in the system, to uncertain and inadequate regulations. For many years, the government warned the people of the evil effects of privatization, and preached the benefits of nationalization. Now, suddenly, all that has to be reversed. 
Iran desperately needs to find financing for its projects in the energy sector. The government must establish market prices in order to discourage waste of resources and curb consumption, while improving production by carrying out the necessary maintenance work and reinjecting gas to raise production levels. If these key measures are not taken, Iran will cease to be a major oil exporter, and will indeed join the ranks of oil importers by the second decade of the next century. It is therefore vital to provide better incentives to private investors - foreign and domestic - in order that they may be reassured of Iran's intentions and willingness to open up its industry. Money needs to be diverted from subsidies, and reinvested elsewhere, if the economy is to avoid the long term impediments to growth that it faces.

The Second Five-Year Economic Development Plan, which was initially scheduled to start in March 1994, has now been postponed until March 1995. Mr. Rafsanjani's presidential term will terminate in 1997, and according to the constitution, he is not eligible to serve a third term. Speculations as to who will succeed him as president are varied, although it can only be hoped that his successor will support and continue the reforms, and that he will not close all doors to the foreign investment desperately needed to revamp the economy.

Iranian oil policies have been enlightened and progressive. Indeed, the oil policy has been among the most successful of Iran's economic policies. Still, the oil policy cannot be seen to operate independently of the economic framework of the government. As such, policies geared toward (i) attracting foreign investment, (ii) removal of subsidies, and (iii) privatization and decentralization of the Iranian oil industry have not been allowed to succeed by the political imperatives of the country. Cooperation and joint ventures with wealthy neighboring nations have been impeded by broader foreign policy differences with regional leaders and the United States.

The policy of the United States in isolating Iran politically and economically has had a long term devastating impact on the Iranian economy. These pressures have also affected the oil sector. While Iran has no problem selling oil to the United States - U.S. companies are Iran's best customers - Iran is not allowed to export oil to the United States. As such, the world's largest oil market, the United States, has been closed to Iran for fifteen years. Foreign investors, both American and non-American, are concerned about investment in Iran, and the potential trade or legal restrictions of the United States. As such, no large scale foreign investments have yet been finalized in the petroleum sector. 
At this stage, it is useful and constructive to compare Iran's case with that of Vietnam. The Vietnamese government opened the doors to large scale foreign investors by offering attractive terms, guarantees of security, and stability of contracts. As the oil companies flocked in from Europe, Asia, and elsewhere, the American companies, seeing themselves at a competitive disadvantage began to lobby for the lifting of their country's sanctions. This made the embargo ineffective, as investment poured in. In the case of Iran, no such campaign has taken place. If Iran had encouraged foreign investment in the industry, the U.S. embargo would have gradually withered away. However, by not providing enough of a stake for non-Americans, Iran has unwittingly allowed the U.S. embargo to be more effective than it might otherwise have been.

The Iranian petroleum policy needs to be freed from the political structure. As the engine of the Iranian economy, it must not be subject to the political oscillations and wrangles in the country. The oil sector must be permitted to be the exception to foreign investment restrictions. It must be allowed to raise domestic prices by up to 500 percent, and given the freedom to restructure, privatize, and revitalize the industry. The industry is capable of handling such freedom very efficiently. Without such a change in policy, the oil industry will slowly draw to a halt, facing reduced output, massive increases in product imports, and an end to exports, with dire political and economic consequences. The gravity of the situation does not yet seem to have been fully appreciated by the political forces in the country. 